I E E S T A F E L.

de Maleische atias Van den heER W. F. Versteeg.

Wanneer een werk bij zijn verschijnen reeds aanstonds door tijdschriften en dagbladen met uitbundigen lof begroet wordt en spoedig daarop zijn schrijver een eersten prijs bezorgt op een internationaal congres in een der hoofdsteden van Europa; dan is het natuurlijk, dat, zoo het onderwerp waarover het handelt, ons eenig belang inboezemt, ook de wensch bij ons opkomt er wat meer te weten. Wij schaffen het ons aan en vormen ons. eigen oordeel er over en zijn het eens met den lof die er aan toegezwaaid wordt of komen daartegen op. Is het in een taal vervat, die wị niet verstaan, dan rekenen wij op anderen, voor wie die vreemde taal zulk een beletsel niet is ow er zich mee bekend te maken. Komt echter niemand van die wij het mochten verwachten er nog eens op terug, dan houden wij het er voor dat allen het omtrent de hooge waarde van het werk eens zijn, en met anderen er over sprekende helpen wij mee den lof er van uittebreiden, die dan als het kringetje in 't water steeds in omvang toeneemt.

Aan het hoofd van dit stukje staat de titel van een werk waarop het hier gezegde zich vrij wel laat toepassen. Dat de Maleische atlas van den heer Versteeg in het Tijdschrift van N. I. met uitdrukkingen, die van de grootste ingenomenheid getuigen, werd aangekondigd en door een niet minder ingenomen jury van het Parijsche congres voor aardrijkskunde den hoogten prijs, een "lettre de distinction" werd waardig gekeurd, is bekend genoeg. Het werk verdient dus, al was het alleen om al dien lof en eer, dat wij er nader kennis mee maken.

Beginner wij met te onderzoeken wat de aanleiding tot die uitgaaf geweest is en op welke wijs de heer Versteeg begrepen

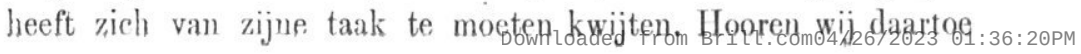


wat hij daarvan zegt in het Inleidend woord dat in het zesde nominer van het Tijdschrift van het Aardrijkskundig genootschap te vinden is. De heer Versteeg zegt daar het volgende: "Het denkbeeld om een school- of volks-atlas te bezitten, "ingericht naar de behoeften van Nederlandsch Indië, is geens"zins nieuw. Voor jaren was daarvan reeds sprake bij het "bestuur der Maatschappij "Tot nut van den Javaan "; doch "de zaak kwam niet tot stand; wat de uitvoering toen verhin" derde is niet ten volle bekend. De behoefte aan zoodanig " werk werd intusschen levendiger gevoeld, naarmate ernstiger " pogingen werden aangewend om het inlandsch onderwijs in "Ned. Indië uit te breiden en op beteren voet te brengen, " en de voorstellen van den Hoofdinspecteur van dat onderwijs, "Mr. J. A. van der Chijs, om die taak van regeeringswege "te doen uitvoeren, vouden een gunstig gehoor, ten gevolge "Waarvan in 1872 tot deze uitgave werd besloten. - Men "had zich daarbij te voegen naar de begiuseleu bij dat inlandsch " onderwijs aangenomen, en deze verschillen in meer dan een " opzicht van hetgeen elders wordt toegepast. - Wordt b. v. " in Britsch-Indië het onderwijs aan de onderscheidene aldaar "wonende volkeren zooveel mogelijk in de Engelsche taal ge"gegeven, in Ned. Indië geschiedt dit in het Maleisch. Dit " moest dus ook de taal van den Atlas wezen. Niet alleen de "gewone aardrijkskundige benamingen als "zee, land, rivier, "kaap enz.", behoorden in die taal te worden overgebracht, " hetgeen trouwens weinig bezwaar opleverde, wijl de zeevarende "Maleiers het meerendeel dier woorden sedert eeuwen bezitten, " maar dit werd ook vereischt voor eenige onmisbare woorden " behoorende tot de wiskundige aardrijkskunde, zooals " evenaar, " keerkring, poolslengte, breedte enz." Dit bood meerdere zwarig"heden aan, wijl de Maleier die namen over het algemeen nog " niet kent; men heeft gemeend het best te doen door deze " soort van namen hoofdzakelijk aan het Arabisch te ontleenen, " aangezien de Maleische taal zelve toch ook overigens daarvan "reeds zooveel heeft overgenomen. - Maar er was meer te " doen, wilde men zich ingevolge het aangenomen beginsel ver"staanbaar maken voor den inlander. - De eigennamen van "landen, zeeën, rivieren, steden, enz. op de kaarten dienden " voor zooveel noodig te worden vermaleischt, althans op zoo"danige wijze te worden geschreven als een Nederlander zich " kau voorstelleu die te hooren wanueer zij dogr een Maleier 
" worden uitgesproken. - Dit was voorzeker niet gemakkelijk " en er wordt dan ook in geenen deele beweerd, dat het werk " " in dit opzicht geheel naar eisch is geslaagd. Hetgeen in dien " zin geleverd is, neme men als een eerste proeve, die zonder "twijfel nog voor veel verbetering vatbaar is." Hierna spreekt de heer V. over de keus der kaarten en verontschuldigt er zich over dat de schoolatlas van lieverlede meer uitgebreidheid kreeg, waardoor hij nu echter ook in wijder kringen meer bruikbaar zal worden. Wij zullen later ook over deze zaken spreken, doch houden ons vooreerst met de taal bezig.

Slaan wij de eerste kaart op. Het is een wereldkaart, gambar doenia, zoo als het daar heet. Die vertaling is slecht Maleisch. Dat woord gambar wordt wel voor ka a rt gebruikt, ofschoon het eigenlijk afbeelding beteekent, maar de Maleijers noemen een kaart liever pěta, een woord dat in de Engelsche Maleische schoolboekjes die al voor jaren te Singapore gedrukt werden en wat de taal betreft, in 't algemeen gesproken, zeer ver de voorkeur verdienen boven de onze, steeds in die beteekenis gebruikt wordt. Een uitstekend kenner der Maleische taal, de heer Klinkert, beweert zelfs dat gambar niet eens Maleisch maar Javaansch is, ofschoon de Maleijers het verstaan. 't Is niet noodig die quaestie hier uit te maken, doch in allen gevalle zal iemand die het woord pěta kent niet aarzelen het voor kaart boven gambar te verkiezen. En wie die met de scheepstermen bekend is, zou niet weten dat men toch ook bij ons ze e ka a t door pěta laoet uitdrukt? - En zoo beteekent nu ook dat andere woord doenija of doenia wel wereld, maar eigenlijk slechts in geestelijken zin, d. i. deze wereld in tegenoverstelling van de andere, dit leven tegenover dat hier namaals. Een groot vorst, een koning der wereld, zoo als oostersche fantasie hem noeint, is niet sjah doenija, maar sjah alam, een vorst van al wat er zich op aarde bevindt. In het woord wereldkaart is met wereld de Aarde, in het Maleisch boemi, bedoeld. Doch op zoo iets let de Hollander in Indië niet wanneer hij Maleisch spreekt, en zoo is dus dat woord maar vertaald door gambar doenia, dat ook de Maleijer wel zal leeren verstaan en gebruiken, in plaats van door het betere pěta boemi. - Of nu verder met die woorden waarvan'er twee boven en een onder de beide halfronden staan en die natuurlijk het oostelijk en westelijk halfrond moeten beteekenen, gemeend is sabelah (l. sabèlah, met doffe e) boemi barat, sabëlah boemi timoer, bij elkaar, of sabèlah boemi, 
half roud, en dan ter onderscheiding er onder oost en west, is niet duidelijk, omdat wij gewoon zíjn die drie woorden te vereenigen en wat het Maleisch betreft de eene uitdrukking al niet veel voor heeft bij de andere en het dus voor den Maleijer wellicht gewenscht ware geweest de woorden niet te scheiden, wanneer zij bij elkaar behooren. Maar de uitdrukking zelt is, zoo als ik zeide, in beide gevallen onjuist. Sabèlah wordt namelijk alleen gebruikt van de eene van twee zaken die wel gescheiden zijn, doch als paar bij elkaar behooren, zoo als bijv. zijn eene (of andere) hand, sabělah tangannja; kadoewa bèlah matanja, zijn beide oogen; maar bij de Aarde heeft zoo iets niet plaats. Wel zegt men, bijvoorbeeld van den bliksem : mëmbělah boemi, den grond splịten, in den grond slaan, en kan men zich dus een sab̌lah boemi als het eene stuk van de zoo gespleten aarde voorstellen; doch dit is hier natuurlijk de bedoeling niet: dat de aarde ooit werkelijk zou gespleten zijn, zoo als in der tijd de maan die Mohammed eerst in zijn mouw gestoken had en die er uit komende zich in tweeën deelde, daarvan heeft de Maleyjer nooit gehoord. Wel gebruikt men het woord sab̌llah bij het begrip bol, in het Maleisch boelatan, zoodat het beter geweest ware oostelijk (westelijk) halfrond uit te drukken door boelatan (eig. boelatan boemi) sab̌llah timoer (barat.)

De werelddeelen worden benoewa (1. bènoewa) genoemd en te recht onderscheiden van de landen op zich zelf, tanah, ofschoon er onder deze zijn die de Maleijer, die aan zulk een onderscheiding noọit behoefte gehad heeft, ook wel běnoewa noemt. De zeeёu heeten semoedra (l. sěmoedra), oc e a a n en laoet, z e e. Omtrent het eerste woord kan men van meening verschillen; ik voor mij zou sěmoedra niet boven laoet verkiezen en liever dit ééne Maleische woord gebruiken voor de beide Hollandsche. Sémoedra is geen gewoon woord. De Maleijer maakt tusschen oceaan en zee geen onderscheid. Die onderscheiding is dan ook noodeloos en willekeurig. Hier heet de Indische zee niet zoo en aan den grooten Oceaan, ofschoon deze de eerste aanspraak op dien naam schijnt te hebben en hij hem ook op deze kaart draagt, komt hịj eigenlijk in 't geheel niet toe. Ik zou dus den Maleijer die verschillende namen liever gespaard hebben. - De noordelijke en zuidelijke IJszeeën heeten op de kaart zee van de noordpool en zee van de zuidpool: het is toch niet om de moeijelijkheid van de vertaling van het woord $I J_{\text {szee }}$ te ontgaan? wat ijs in het Maleisch is, behoef ik iemand die 
in Indië geweest is wel niet te vertellen. Maar waarom dan in plaats van dien gewonen en beteren naam, in het Maleisch laoet ajar běkoe, een anderen gesteld, dien de Maleijer geheel anders opvat, t.w. als de zee rondom de pool en niet tot nog bezuiden den poolcirkel, tot zoover het ijs reikt, iets dat vooral verkeerd zal zijn wanneer het eenmaal waar mocht blijken, althans van de noordpoolzee, dat die een ijsvrije zee zou wezen? Maar dat laoet koetoeb oetara, zee van de noordpool, is althans geen Maleische taalfout. - Dit zou men niet kunnen getuigen van laoet tengah (l tëngah), zoo als ik voor Middellandsche zee vind. Laoet tëngah is wel goed Maleisch, maar beteekent geheel iets anders dan er mee bedoeld is, het beteekent middelzee, zoo dat de Maleische schnolknaap zijn best zal doen de beide andere zeeën op te zoeken, waar tusschen deze midden in ligt. Het had moeten zijn laoet mĕnĕngah tanah. In den omtrek van de Middellandsche zee stuit ik wederom op andere zaken. Waarom Egypte Tanah Mesir (1. Měsir) en de Roode zee Laoet Kolzoem genoemd, zoo als in 't Arabisch, maar Marokko, Algiers niet op zijn Arabisch? Tanah Magrab is den Maleijer anders even goed bekend als Měsir. Ik zou beide namen gewenscht hebben, de Arabische en de gewone, want zoo hị nu eens van Tanah Igip of Idjip en van de Laoet merah hoort, dat toch zeer mogelijk is in dezen tijd, dan helpt hem zijn atlas niets. Mij dunkt het ware praktischer geweest. - Onmiddellijk aan de noordkusten van Afrika grenst de Goeron bèsar Sahara, waar goeron, een zeer verdacht woord, dat echter ook in de vertaling van het Oude Testament voor woestijn voorkomt, a!leen daarom schijnt gekozen, omdat men padang pasir, d. i. zandvlakte, zoo als men ook zegt en dat zich terstond als een goede uitdrukking aanbeveelt, niet in de gedachte kreeg. Bij zulke benamingen had men zich ook wel mogen afvragen of het goed was Sahara zoo maar achter aan te zetten en men niet liever inoest zeggen jang bërnama Sahara, want zoo als er nu staat is het de woestijn van Sahara, zoo als wij ook zeggen de woestijn van Libye.

Op een wereldkaart kan het mij niet verwonderen den naam Kanaal van Suëz te inissen. Ik vind het op kaart no. 14 met slokkan Soe-es (lees Soeweis) weergegeven. Slokkan of slokgang, zoo als dat Bataviaasch-maleische of liever Soendaneesche woord solokan ook wel verbasterd is, beteekent een grachtje en schijnt dus aan den Maleijer, zoo hij het woord begrijpt, geen waardig 
denkbeeld van dat kanaal te zullen geven. Waarom niet kort en goed Sëlat Soeweis, Straat van Suëz? en laat men er dan des noods bij vertellen dat die straat eigenlijk gegraven is. - En de landengte van Suëz? Dat woord landengte vind ik nergens in den Atlas door een Maleisch woord uitgedrukt, ook niet bij Panama, waar men het wel het minst gaarne mist. Het is toch niet omdat de auteur er geen naam voor wist? of was het verlegenheid met de keus? want daar zijn er wel drie, die men elders gebruikt vindt, aan het bod: pělantaran, eigenlijk een verbindingsweg, en dus ook wel eens een enkele brug, tusschen twee landen of oevers; gènting tanah, eig. een landvernaauwing, en leher tanah, een landhals. Ofschoon de Engelsche schoolboekjes het tweede woord gebruiken, zou ik bepaald het laatste verkiezen. Zulke figuurlịke benainingen verdienen in gevallen als wij hier hebben de voorkeur boven andere, omdat zij tevens schilderen en zij dus terstond verstaanbaar zijn, ook al heeft men ze nooit in den nieuwen zin aangetroffen dien men haar geven wil. Zoo is het bijvoorbeeld ook met schiereiland, waarvoor ik in den Atlas insgelijks een Maleisch woord mis, ofschoon dit bij Kamschatka, Kalifornië en elders best had kunnen gebruikt worden. Men heeft er in het Maleisch voor ingevoerd tanah mënandjoeng, vo or uitstek end land, doch ook ekor tanah, landstaart, dat ik wederom, om bovengemelde reden, verkies, ofschoon ik het liever voor land tong zou willen bewaren. In plaats van landengte, schiereiland, vind ik nu slechts land, tanah. Bij het uitdrukken van de onderdeelen der zee is men omgekeerd weer te gul met zijn Maleische termen geweest. Door wat meer soberheid had men zich buiten de tout gehouden van overal těloek te gebruiken, waar wij golf of baai zeggen. Een Maleijer gebruikt dat woord zóó althans niet uit zich zelf, en zegt bijv. niet tèloek Aden voor Golf van Aden, maar laoet Aden, zee van Aden, eveumin als sèlat Malaka, straat van Malakka, voor laoet Malaka; maar wel bijvoorbeeld sělat Singapoera, die zij als zoodanig overzien kunnen.

Maar stappen wij van dit onderwerp af en onderzoeken wij wat de auteur van dat vermaleischen der woorden, zoo als hij het noemt, gemakt heeft. Het best zullen wij dit kunnen beoordeelen door de kaart van ons land op te slaan. (Op tweeërlei wijs heeft de schrijver zijn doel trachten te bereiken en wel vooreerst door de spelling der woorden te veranderen, door ze namelijk zóó te schrijuen als de Maleijer naar het gehoor van 
den Nederlander die zou uitspreken, en ten auderen door ze, voor zoover dit ging, te vertalen. O Dornseiffen, Dornseiffen! hadt gij de mogelijkheid kunnen gissen dat er aan uwe lessen over de taal der aardrijkskunde zulk een behoefte bestond, ze waren zeker nog tijdig genoeg in het licht gekomen om het rampzalig lot van zulk een menigte eerlijke hollandsche eigennamen op de kaart van ons land in dezen Atlas te voorkomen! $\mathrm{Nu}$ is het te laat geweest. Maar ieder die het inleidend woord van de heer Versteeg leest zal toch in hetzelfde stukje van uw woorden kunnen kennis nemen!

De verandering der spelling betreft zoowel klinkers als medeklinkers, doch van beide slechts enkele. De $u$ wordt geregeld vervangen door oe, zoo als in Boeren, Soetfen, Oetregt, Oerk, Voersge, Boessoem, Broemen, Broessel; de $\ddot{i j}$ door $e i$, als in Weik, Neimegen, Weighen; de ou door ow (zooals ook de $a u$ door $a w$ ) of door ol: Wowbroegge, Woldeuberg, Renswowde, Skowen; de ui blijft doorgaans onveranderd, zoo als in Huissen, Kuik, daarentegen Loeik, Loeikgestel. Oe blijft zoo, zelfs in Doetighem waar wij eu uitspreken. Schrijfwijzen als Leewarden, Niewe Diep en nog enkele andere misschien behoeven naauwlijks bijzondere vermelding. - Bij de medeklinkers bestaat de verandering slechts daarin dat $c h$ in $g, s c h$ in $s k$ of $s g$ overgaat, bijv. Skiedam, Sgaik, Oirsgot, Walgeren, Diekirg, en dat de $h$ na een voorafgaanden $t$ en $r$ soms wegvalt, zoo als in Tolen, Renen, maar niet in Drenthe, en ook altijd $f$ voor $p h$ staat, bijv. San Filipsland, doch niet na de $g$, zoo als in Doetighem, Loghem. De $z$ verandert in $s$ en de $c h$, waar hij die klank voorstelt, in $s j$ zoo als Neusen; Sjarlois. Dat de oi $o$ is wordt de Maleịer verondersteld wel te begrijpen. Maar om de doffe $e$ van de heldere te onderscheiden, dat voor de Maleische uitspraak een allereerst vereischte is, zoo als wij reeds in dit stukje meermalen hebben kunnen opmerken, daaraan is nergens gedacht.

Ik geloof niet te ver te gaan met te zeggen dat deze vermaleisching der spelling geen de minste waarde heeft. Op fouten als daar zijn Doetichem, Weichen, Oirsgot, Boessoem (wie ter wereld spreekt Bussum uit, al spelt men zoo?) en dergelijke, alle het gevolg eener onovertroffeu oppervlakkigheid, wil ik nu niet eens letten; zij bepalen zich trouwens, uit den aard der zaak, tot slechts enkele woorden. Maar er zijn een paar andere zakeu oin op te merken. Vooreerst, zoo als de heer Dornseiffen ous het ook uitlegt en wel op zulk een wijs dat ik daarvoor naar 
zijn stukje verwijzen kan, dat het reeds in $t$ algemeen verkeerd is om de schrijfwijs van geographische namen te veranderen, wanneer de letters waarmee die geschreven worden ons bekend zijn of zij niet reeds in den veranderden vorm het burgerrecht hebben verkregen. En dan dat de genomen proef volkomen mislukt is, omdat nu dat wat veranderd is doorgaans verkeerd veranderd en wat zoo gelaten is dikwijls nog verkeerder onveranderd gebleven is. - Onze $u$ is voor den Maleijer nooit oe maar klinkt hem veeleer als $i . O w$ en $a w$ zijn voor den Maleijer niet uittespreken; hij zegt voor die klanken ou en au, aoe, zoodat Gaoeda beter zou geweest zijn dan Gowda. Waarom Woldenberg en dergelijke, is en blijft mij een raadsel; ol komt midden in het woord in geen Maleisch woord voor. Toonen zulke veranderingen reeds groote onbekendheid met de Maleische uitspraak, vele niet veranderde namen toonen die in nog veel erger graad. Zoo is het bijvoorbeeld een eigenaardigheid van de Maleische woorden, die in de allereerste plaats opmerking verdient, dat zij nooit op twee medeklinkers uitgaan. De Maleijer kan niet goed twee medeklinkers achter elkander uitspreken, aan het einde noch in het midden der woorden, tenzij wanneer de eerste letter een neusletter is, en is de tweede een vloeijende dan gaat het met de uitspraak natuurlijk ook wat gemakkelijker, zoo beide letters ten minste niet op het einde staan. Deze eigenaardigheid schijnt den auteur evenwel ten eenenmale onbekend te zijn geweest. En daarbij komen dan natuurlijk nog andere, die het te ver zou leiden hier alle onder regels te brengen. Zoo kan men bijvoorbeeld voor het Maleisch ook als regel stellen dat een $w$ waarmeê een woord gegint, zooals in Woldenberg, altijd $b$ wordt. Van daar Bělanda, dat uit Wělanda, voor Oelanda, Olanda, zoo als de Portugeezen Holland noemden, ontstaan is. De Javanen behouden die $w$, de Maleijers niet. Wanneer het dus om een goed Maleischen vorm te doen is behooren al die woorden die met $w$, even als die met $v$ begimen, veranderd. Zoo schijnt de auteur ook niet te weten dat de $f$ door den Maleijer niet anders dan als $p$ kan worden uitgesproken, en hij dus nooit Alfen, Soetfen, Friesland zal zeggen; juist zoo als iemand dit reeds vermoeden zou, die, er niets van wetende, op de kaart tanah Prasman (Franschman) ziet staan. F'riesland, Gelderland, Holland, Zeeland, Utrecht enz., al die provincienamen, die op Oetregt na op de kaart niet veranderd zijn, ziju zoo als zij dat gespeld stan voer den Maleijer niet uit te spreken, en 
Oetregt evenmin als Utrecht. Vooreerst moet de laatste letter er af, zoo er niet, zoo als in Bělanda, om bijzondere reden nog een bijgevoegd is. Friesland kan een Maleijer niet anders uitspreken dan Pri-sělan; Groningen zou waarschijnlijk Gëroning of Gëroening of Këroening worden; Drenthe, Dëren of misschieu Dërenta of Direnta of Direnti; Overijssel Oeběrisal en bij meer gebruik misschien Bérisal of Bèrisala of wie weet wat; Gelderland, Geldèr- of Keldèrlan; Utrecht, Itèrek of Térek; Holland Olan of Bèlanda; Brabant, Bèraban of Bèrabanda of Bërabang; Zeeland, Seilan; Limburg, Limboer of Limboeroek. En hetzelfde zou natuurlijk met een aantal andere plaatsen het geval ziju, die nu onveranderd zijn gebleven, zoodat nu al die letterveranderingen in andere woorden zoo in den steek gelaten natuurlijk een hoogst ongelukkige figuur maken.

Maar behalve door die letterveranderingen heeft de auteur nog op andere wijs zijn doel trachteu te bereikeu. Ein hij is daar zoo mogelijk nog ongelukkiger mee geslaagd. $\dot{W}_{i j}$ zagen reeds dat hij ze ook nog, zoover het ging, vertaald heeft. En dit gaat nu desnoods nog wanneer het om een nie uw of oud te doen is (otschoon men in een Duitschen atlas toch te vergeefs naar een Neu- of Alt- in de zamenstelling van Hollandsche geographische namen zal zoeken, denk ik), zoo als in Beijerland baharoe en B. toewah (in welke namen de $\ddot{i j}$ niet volgens den aangenomen regel in ei veranderd is, en waar dat toewah zoo als in alle namen waar het oud moet beteekenen met een $h$ gespeld is in tegenspraak met de aangenomen spelling zonder $h$, omdat men het woord met de $h$ spelt als het geluk beteekent); of om noord en zuid, oost en west, bijv. Blokker timoer en Blokker barat, tanah Holland oetara en T. H. sělatan, doch wederom Noordlaren en Suidlaren; of om binnen of buiten, zoo als Eemnes dalam (dat eigenlijk beteekent het diepe Eemnes) en $\boldsymbol{E}$. loewar, en Standdaard loewar voor Standdaar (sic!) buiten : want Egmond buiten, Katwijk buiten is E. aan zee, K. aan zee, dat vertaald is door $\boldsymbol{E}$. $\boldsymbol{K}$. dekat (l. dékat) laoet (in plaats van het betere jang di těpi laoet, want wat er nu staat wil eigenlijk zeggen niet ver van de zee), zoo als, let wel, ook Wijk bij Duurstede op de kaart voorkomt als Weik dekat Doerstede! Het nog overblijvende Egmond, Egmond-op-den-hoef, is vertaald door $E$. pada latar, welk woord latar geen Maleisch maar Javaansch is en dus door eeu Maleijer wel nauwelijks verstaan zal worden, en 
in het Javaansch beteekent plein, voorplein voor een $\mathrm{hu}$ is, terwijl het wederom in latar Hipolitoes dient om Hippolytusbuurt, en in latar Werver weder om Werversh oef uit te drukken. Een fraaije vertaling is ook de Hoeksche waard door tanuh beterbis (l. bětèrbis) Hoek, met welke woorden tanah beterbis, op gezag waarschijnlijk van Roorda van Eijsinga's Woordenboek, polder bedoeld wordt, zoodat die Maleische eigennaam dus Polder Hoek weergeeft of Polder van Hoek, want hoek als algemeen zelfstandignaamwoord is, zoo er een uiterste punt mee bedoeld wordt, gelijk bij ons in hoek Krawang en dergelijke uitdrukkingen voor $\mathrm{k}$ a a p Krawang, in het Maleisch oedjoeng, dat ook op de kaart gebruikt is in Zevenbergschen hoek, Oedjoeng Sevenbergen, een klein plaatsje dicht bij Zevenbergen (dat op de kaart ontbreekt). Dat polder en wa ard heet nu ook elders eveneens, zoo als bijv. tanah beterbis .Anna Pawlowna, tanah beterbis toewan Iloegoo (Heer Hugo-waard), doch Wieringerwaard (dat trouwens op de kaart niet als tanah land, maar alleen als naam van de gemeente voorkomt) blijft onveranderd en de Beemster en de Schermer heeten eenvoudig tanah Beemster en tanah Skermer, ofschoon men, wat wel het ergste is, nu weder vindt Tasik negri (l. nagěri) Haarlem, voor Haarlemmermeerpolder, waar de Maleijer zich verbazen zal geen meer, tasik, maar niets dan land, tanah, te outdekken. Zoo is nu verder de Zuiderzee laoet selatan (l. sělatan) geworden: men verbeelde zich een Mer $d u$ sud of méridionale! en hoe de Maleijer het hoofd zal schudden over die Hollanders, die de laoet oetara, de Noordzee, in het westen, en daar naast, ten oosten er van, de laoet sělatan hebben! En in het" noorden loopt langs Friesland en Groningen (door de teloek (l. těloek) Lawers, hier toch Laauwerz e e ! gescheiden) de Stra a (NB.) de Wadden, sělat de Wadden!

Ook op andere kaarten zijn er aardige vertalingen, zoo als Tanah idjoe, het Groene land, Terre verte, voor Groenland, dat echter op de kaart van Amerika gelukkig onvertaald blijft; maar daarvoor worden wij er schadeloos gesteld door wat er onmiddellijk onder staat, tanah Amerika Denemarken, dat onder de Maleijers geen mensch begrijpen kan, en, het fraaiste misschien van alles, geheel onderaan, T. Slamat voor Kaap Vaarwel, dat de Maleijer bij eenig nadenken zal kunnen opvatten in den zin van $\mathrm{Ka}$ ap der behoudenis. Hoe is het mogelijk in een werk als

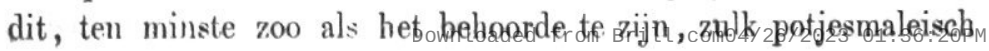


te gebruiken als de Hollanders in Indië dit gewoon ziju! want een Hollander in de Oost zal T. Slamat, ka ap (Ikwensch-je) Gezondheid wel verstaan; maar voor de Hollanders in Oost-Indië is toch deze atlas niet gemaakt? - Nog een aardige vertaling is die van St. Janssteen, in Staatsvlaanderen, door San (zoo als overal Sint is weergegeven, als of de $a$ hier meer recht had dan onze i) Jahja (de Arabische naam die met ons Johannes, Jan, overeenkomt) Steen (als of men aan Jan Steen gedacht had! waarom niet batoe? omdat het dan zou beteekend hehben Sint steenen $J$ an of steenen Sint Jan). Bij San heb ik nog een fraaije vertaling: Kota San Anna en Kota San Jakobi (sic!) d. i. de versterkte plaats, vesting (ofschoon Ommerschans vertaald is door Koloni benting Ommen) van Sint Anua en Sint Jakobi, voor St. Anna- en St. Jacobiparochie! $\mathrm{Nu}$ zijn dit slechts kleine plaatsjes waar het bijna een onschuldig spel is zijn krachten aan een vertaling te beproeven, zelfs al vertaalt men het eiland De Tien gemeten, door $P$. Sapoeloh bahoe, het eiland van tien bouws, daar tien gemeten slechts zes bouws uitmaken. Maar hoe nu bij plaatsen van meer belang? Wat vindt een Maleijer bijwoorbeeld wanneer hij in zijn atlas naar de Kaapstad zoekt of naar Capetown, welken naam het voor hem van althans gelijk praktisch nut is te kennen? Niets wat er ook slechts naar gelijkt. Maar zulk een bekende plaats kan toch in zijn atlas niet ontbreken? $\mathrm{Z}_{\mathrm{ij}}$ doet dit ook niet: de naam Tandjoeng pengharapan (l. pëngharapan) $\mathrm{K}$ a ap der hope, koint zelfs tweemaal op de kaart voor: eens met kleine letters, als kaap, eu eens met grootere, als stad, vlak onder Tel.gnenoeng medja, de Tafelbaai. Ware het niet beter geweest den Maleischen schoolknaap den Engelschen naam te leeren uitspreken en het er bij vertellen en verklaren van die beteekenis aan den meester over te laten? Want wat heeft hij er in de praktijk aan? Men verlangt toch niet dat hij leere in 't vervolg een brief voor de Kaap te adresseeren naar T. Pengharapan? Dat zou niet zoo heel veel minder erg zijn dan wanneer wij dat deden naar de stad der Vliegende honden (Pekalongan) of van het Geurige water (Banjoewangi). Ja, al is de naam slechts gedeeltelijk vertaald, het wordt er niet veel beter door. Wat moet men bijvoorbeeld van dat Weik dekat Doerstede denken, daar de Maleijer te vergeefs naar dat schijnbaar zoo voorname Doerstede zal zoeken en bij het vragen er naar gevaar loopt dat ieder Hollander hem uitlacht; terwijl wanneer men hem van Wijk bij Duurstede 
spreekt, hij op zijn beurt dien naam nog moeijelijker zal verstaan? Wat dezen atlas in de eerste plaats onderscheidt van een Hollaudschen, de taal, die brengt den Maleijer, voor wien hij bestemd is, meer nadeel dan voordeel aan.

Omtrent hetgeen de heer Versteeg in zijn Inleidend woord nog verder van dezen atlas zegi, kan ik kort zijn. Dat een Maleische knaap meer aan speciale kaarten van Oost-Indië heeft dan aan zulke van Europeesche gewesten, is voor iedereen duidelijk. Ieder goede schoolatlas en handatlas der aarde zal met het oog op de gebruikers uitvoeriger zijn in het voor hen meer belangrijke, minder uitvoerig in het overige. Maar of dit nu wettigt dat men na de wereldkaart de kaart van Azie vóór die van Europa laat gaan, dit betwijfel ik. Voor een ieder is wel de naaste omgeving van meer belang dan het verder liggende, maar het is iets voor een Chinees om nu ook geheel Azie aan Europa vooraf te laten gaan, omdat hij in Azie geboren is. Dan had ook Australie wel als tweede kaart mogen volgen en niet, zoo als nu, geheel achteraan komen. $\mathrm{Nu}$ is er slechts een begin van beraad geweest over de volgorde der kaarten; de Oostindische archipel en het overige Azie zijn nommer één geworden; doch verder is men niet gegaan. Al het andere behoudt zijn volgorde. Voorts is er voor ons land een uitzondering gemaakt op den regel om buiten Azie van geen enkel werelddeel speciale landkaarten te geven. Voor Engeland, bijvoorbeeld, moet zich de Maleijer met de kaart van Europa vergenoegen. Doch neen, er is nog een klein staatje in Europa dat in den Atlas op een zesmaal grootere schaal dan Engeland voorkomt. Het is Luxemburg! Begrijpelijk is het alweer. Luxemburg vergezelt nog altoos op vele kaarten ons land, als zijn ouderen neef. Het is als of het er een deel van uitmaakt, als of het zich niet van ous land laat losrukken, terwijl het'er tosh volstrekt niets mee te maken en er niets mee gemeen heeft dan de achting voor onzen Prius Hendrik. Maar dit zal toch de reden niet zijn dat wịj Luxemburg ook in den Maleischen atlas terug vinden. Dat overnemen zal wel geschied zijn zonder er veel bij te denken. Maar nu de Maleische schoolknaap dus ook een kaart van Luxemburg heeft, en wel op een zesmaal grootere schaal dan Engeland, nu mag men veronderstellen dat, zoo al niet wij, dan hij toch wel eens zou kunnen vragen, waartoe? En wanneer men dan meer aan dien lastigen vrager zou moeten antwoorden,

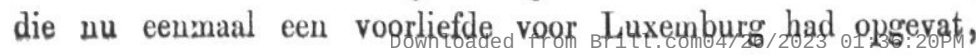


zoo als hij begreep dat blijkbaar die Hollanders immers ook hadden: waarom anders ongevraagd een extra-kaartje van dat land gegeven ? - Wanneer hij bijvoorbeeld vroeg: Is Tuxemburg even vlak als Holland, want ik zie er geen enkelen berg in? of: ik kan niet goed zien welke eigenlijk de hoofdrivier van het land is (de Maleijers houden veel van rivieren), want bij de riviertak, die uit de Moèzel komt, staat geen naam? wat zou men antwoorden? En dan is er nog zooveel op die kaart ik zal maar vertrouwen dat alle andere heel veel beter zijn - dat de knaap aan zal moeten nemen, zonder dat zelfs het vermoeden van onjuistheid bij hem opkomt! Komt de naauwkeurigheid der ligging, de naauwkeurigheid van de namen der plaatsen er niets op aan? Waarom Wormeldingen (Walmerdange der kaart) niet aan de Moezel ligt en Steinfort niet vlak aan de Belgische grenzen en Beltingen, lees Bettingen, zoo ver van Dippach, waar het op zulk een kaartje mee moest zamenvloeijen? Waarom Bivers, Mighelme, Molstoem, Filts, Kemersjen zoo gespeld zijn voor Büwisch, Michelau, Consthum, Fels, Remerschen? Zijn dat altemaal graveerfouten? 't Is mij wel. Maar met welk recht zijn verscheiden volstrekt onbeduidende plaatsjes, dat Bivers en Molstoem, Arsdorf, Grosboes, Steinfort, Dippach, Oetringen enz. op de kaart opgenomen en niet plaatsen die het verdiend hadden, zoo als Esch aan de Alzette, om haar ijzerhutten, Ettelbrück om haar jaarmarkten, Walferdingen, om haar lustslot, Mondorf, om haar baden, Dalheim, om de Romeinsche oudheden, enz.? Wat beteekent het, dat alleen Diekirch, Echternach en Greveumachern met grooter letters geschreven staan dan de overige plaatsen op de hoofdstad na? Ware het om de voornaamste plaatsen des lands te doen geweest, dan had Wilts evenveel recht op die onderscheiding gehad; of om de hoofdplaatsen der distrikten, dan had Echternach er niet bij behoord. De teekenaar der kaart kende van de geographie van Luxemburg volstrekt niets. - Nu weet ik wel dat het hier slechts de kaart geldt van een klein en voor dezen atlas een der minst beduidende landjes, waarop zooveel is aan te merken; en ook, dat de verwaarloozing van zoo iets gerings nog wel kan gepaard gaan met een meer zorgvuldige behandeling van het meer belangrijke; doch het kan niet anders of het vertrouwen op de deugdzaamheid van het overige moet er onder lijden. Het vervaardigen van kaarten, van de kleinste zoowel als van de grootste, is even goed een wetenschappelijk werk als ieder ander 
dat dien naam verdient, maar in de praktijk schijut die waarheid nog zeer weinig ingezien te worden.

De slotsom mijner opmerkingen kan niet twijfelachtig zijn. De Maleische atlas is een eerste proef, zoo als de heer Versteeg zelf de eerste geweest is dat te erkennen. Maar de moed waarmee hij die, op zijn talenten vertrouwende, genomen heeft, is, naar het mij voorkomt, overmoed geweest. Want het is een mislukte proef. Noch als Maleische atlas, noch als schoolatlas voor den Maleischen knaap of als atlas voor den meer ontwikkelden Maleijer heeft hij waarde. Zijn eenige waarde ligt in die enkele kaarten van sommige Oost-indische eilandeu die door het gebruik maken van nieuwe bronnen beter zijn geworden dan de tot dusverre bestaande. Voor die bijdrage tot de kemnis van den Oostindischen Archipel komt den heer Versteeg onze dank toe. Jammer maar dat die kaarten niet in het Hollandsch zijn.

Leiden, September 1875.

Dr. J. Pijnappei.

DE PAPOEA'S VAN NIEUW-GUINEA.

Anthropologische Mittheilungen über die Papuas von New-Guinea. I. Auesserer physischer Habitus. Vortrag gehalten in der Anthrop. Gesellsch. zu Wien am 10 Febr. 1874 von Dr. Adolf BerNhard MeYer. Mit einer Tafel Porträts. Wien, 1874. in 80 .

Heeft ons geacht medelid dr. H. Kern, te Leiden, in het laatst verschenen stuk dezer Bijdragen de aandacht gevestigd op een over de Mefoorsche taal handelend geschriftjen des heeren dr. A. B. Meyer, voor ons ligt thans een ander, dat oorspronkelijk opgenomen is in de $n^{08}$. 3 en 4 , deel IV van de "Mittheilungen der Anthropologischen Gesellschaft in Wien", en waarvan een "Separatabdruck" in ons bezit is. Het bevat, gelijk reeds uit den titel blijkt, eene voorlezing van den schrijvèr, te Weenen gehouden. De inhoud daarvan berust op juiste waarneming en grondig onderzoek. Wat wij daarin aangeteekend vinden aangaande het uiterlijk voorkomen, de huid, het haar en de physionomie der Papoea's, is zeer belangrijk

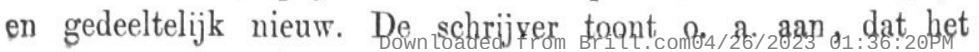


haar niet bundels- of vloksgewijze over den schedel verspreid groeit, zooals vele reizigers, gelijk Earl, Wallace, e. a. beweerd hebben, in welk denkbeeld ook ik vroeger deelde, maar dat de haren op den haarbodem der Papoea's eveneens verspreid zijn als bij den Europeaan. Van een bijzonder belang zijn ook de tot opheldering van den inhoud bijgevoegde profielportretten. Op welke grouden echter de Schrijver Mafoor en niet Mefoor, Mysore en Kordo schrijft, is ons onbekend; onze zendelingen en de Papoea`s kenuen slechts Mefoor en Korrido, terwijl Mysore eene verbastering is van Meos-soir, door de Mahomedaansche handelaars in zwang gekomen, doch voor den bewoner der Schouten-eilanden onverstaanbaar. $O_{p}$ wiens gezag eindelijk de heer Meyer op pag. 5 zijner brochure de in de Vorstenlanden op Java woonachtige Kalang's kroesharig noemt, tot de Negritos rekent en ze als het gering overschot der aborigines vau Java beschouwt, weten wij insgelijks niet. De uitvinding van Negritos op Java ware eene belangrijke wetenschappelijke nieuwigheid; doch helaas! zijn de Kalang's noch kroesharig noch Negritos; zelfs de volksoverleveringen weten niets van zulke menschen op Java te verhalen, en valt derhalve deze fraaie bewering in duigen.

Ten slotte dezer aankondiging voegen wij nog eene aanteekening bij, welke echter geenszins strekt om de verdiensten van den heer Meyer te verkleinen, die wij, door onze herhaalde reizen naar Nieuw-Guinea daartoe in staat gesteld, hoog waardeeren.

In $n^{0} .42$ van het loopende jaar vau het tijdschrift" Ueber Land und Meer" vinden wij onder de rubriek "Notiz-blätter" eene aanteekening, waarin de heer Meyer "einer der gründlichsten Kenner des Malayschen archipels" en als de eerste genoemd wordt, die het reisverhaal van Lawson naar Nieuw-Guinea als fictief aan de kaak heeft gesteld. Tegen beide beweringen moeten wij als ongegrond opkomen. Het is immers ongerijmd dat iemand een grondig kenner onzer Oost-Indische koloniën genoemd kan worden, die slechts enkele gedeelten daarvan (het noorder-schiereiland van Celebes, Ternate, een luttel gedeelte van Nieuw-Guinea en enkele der daaronder behoorende eilanden) bereisd en die wijders het reisverhaal van den beroemden Wallace uit het engelsch in het hoogduitsch vertaald heeft. Wij zouden een tal van personen hier te lande en in Indië kumnen opnoemen welke met land en 
volk onzer koloniën verreweg beter bekend zijn dan de heer Meyer.

Wat Lawson's reisverhaal betreft, zoo heeft het in Londen veischijnende tijdschrift "The Athenaeum" reeds voor eenigen tijd geleden de verdichting daarvan aangetoond.
Den Haag, Oct. 1875.
C. H. B. von Rosenberg.

TOELICHTING EN AANMERKING VAN DR. A. B. MEYER

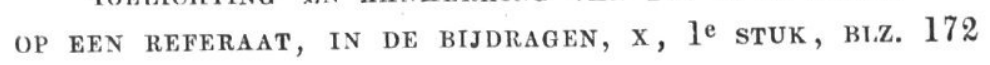
EN 173 EN NASCHRIFT VAN DR. H. KERN.

Naar aanleiding van een referaat des heeren Dr. Kern, in 't vorig nummer dezer Bijdragen geplaatst, ontvingen wij van Dr. A. B. Meyer, Directeur van het Koninklijk Museum voor natuurlijke historie te Dresden, een schrijven, dat wij hieronder laten volgen tegelijk met 't Naschrift, dat de hoogleeraar Kern daaraan heeft toegevoegd. De brief van den eerste luidt:

\section{"Hooggeachte Heer!}

"In het $\mathrm{X}^{\mathrm{e}}$ deel, $1^{\mathrm{e}}$ stuk der "Bijdragen tot de taal-, landen volkenkunde van Nederlandsch-Indië door het Koninklijk Instituut te 's Hage", pag. 172 en 173 - welk deel ik zoo even ontving - bevinden zich bij gelegenheid eens referaats van den heer Kern over 4, de mafoorsche taal betreffende kleine geschriften eenige bemerkingen, die van mijn kant na dere toelichtingen vereischen, dewelke ik $\mathrm{U}$ beleefdelijk verzoek het genootschap in de eerstvolgende vergadering voor te leggen en in zijne notulen te willen doen publiceeren.

Het bevreemdt den heer Kern dat noch engelsche, noch italiansche, duitsche, russische of nederlandsche geographen, ethnologen e. z. v. die zich laatsttijds met Nienw-Guinea hebben bezig gehouden, gewagen van de schriften der zendelingen aldaar over de mafoorsche taal, en hij berispt deze onverschilligheid namentlijk bij mij.

Blijkbaar is het den heer Kern ontgaan dat ik bereids iu December 1874. (de verhandeling is gedagteekend: Dresden, November 1874) in een aanhangsel tot mijn geschrift "Über die "mafoorische und einige andere Papua Sprachen auf Neu Guinea" 
hetwelk in denzelfden jaargang der "Sitzungsberichte der Kai"serl. Academie der Wissenschaften zu Wien" verschenen was, niet alleen drie hierop betrekking hebbende geschriften aanhaal, maar ook uitdrukkelijk aangeef waarom dit aauhangsel eerst eenige maanden na de hoofdverhandeling kon worden uitgegeven, en daarmede ook de gewag van de betrekkelijke geschriften (pag. 525, deel LXXVIII).

En hiermede vervalt ook het verwijt hetwelk de heer Kern mij te maken een recht vermeende te hebben, en wanneer dezelve buitendien laat doorschemeren dat ik de verdiensten des heeren van Hasselt om de mafoorsche taal niet toereikende recht laat wedervaren, zoo kan ik mij zulks slechts daardoor verklaren dat hij de duitsche taal niet voldoende magtig is, om den zin mijner woorden te verstaan.

Mijne verhandeling, pag. 299, deel LXXVII van de "Sitzungsberichte der Kaiserl. Academie der Wissenschaften zu Wieu ", begint met de woorden: "I $\mathrm{k}$ verdank de navolgende mede"deelingen over de mafoorsche taal grootendeels aan den bereids "sinds vele jaren in de bogt van Doré gevestigden zendeling, "den heer van Hasselt; dezelve legde zich gedurende zijn nage"nnoeg tienjarig verblijf op Nieuw-Guinea met bijzondere voor"liefde op de studie der taal van den mafoorschen stam. Ik zelf "werd door de omstandigheden maar weinig gedrongen eenige "taal of dialect van dit groote eiland aan té leeren met het doel "mij te doen verstan, daar ik door intelligente tolken verge"zeld werd, die maleisch en onderscheidene papua-dialecten "verstonden."

Ik vermeen dat dit ondubbelzinnig en klaar gesproken is!

Wat echter aan de bemerking van den heer Kern, als zou men het boekske van den heer van Hasselt over de mafoorsche taal en de vertaling van het evangelie van St. Marcus hebben verzwegen, eene eigendommelijke kleur geeft, dat is de omstandigheid dat hij 6 regels lager zelf zegt: "Het boek van den heer van Hasselt is niet in den handel." Hoe dus kan men er zich over verwonderen dat het niet geacht wordt, of hoe kan men iemand het verwijt doen het te hebben verzwegen?

Ik laat het aan den heer Kern over deze tegenspraak op te lossen, moet echter diens verklaring nog in zoo verre rectificeeren als geen eene der hiertoe behoorende geschriften in den handel voorkomt. Ja, er is meer. Tijdens mijne aanwęzigheid op Nieuw-Guinea bezat zelfs de heer van Hasselt geen 
exemplaar van ziju geschriftje, noch was hij er over georienteerd of dit geschrift, waartoe hij voor lang het manuscript naar Europa gezonden had, door den druk was uitgegeven of niet; en toch was, zooals thans uit de mededeeling van den heer Kern blijkt, het betrekkelijke geschrift destijds reeds sedert 5 jaren gedrukt!

Hoe moeielijk het zelfs in Nederland moet wezen zich over het bestaan of niet bestaan van dusaardige zendelingsgeschriften te orienteeren bewijst de onstandigheid, dat deu heer Kern bij zıjne. opsomming der geschriften in de mafoorsche taal, twee, in 1870 en 1871 in het licht gegeven, ontgaan zijn, op die ik mij bij deze gelegenheid dus veroorloof in Nederland de aandacht te vestigen. Ze zijn:

1. Faijasi rijo refo manseren Allah biëda kiawer kwaar ro woos woranda be woos noefoor. Ro J. G. Geissler, Pandita ro Mausinam (N.-Guinea). Utrecht, Kemink en Zoon. 1870. 269 pag. $8_{0}$. (Bijbelsche geschiedenissen van F. L. Zahn, vertaald door J. G. Geissler, enz.)

2. Psalmen en gezangen in de Noefoorsche taal. Uitgegeven door de Utrechtsche Zendelings-vereeniging. Utrecht, Kemink en Zoon, 1871. 144 pag. $8_{0}$.

Ongetwijfeld trachten de uitgevers het te verhinderen dat deze zendelingsgeschriften in den boekhandel komen, daar zij anders in zulk een wel georganiseerden boekhandel als de nederlandsche niet konden verborgen zijn gebleven.

Dat zij echter inderdaad niet in den handel te verkrijgen zijn, bewijzen ten genoege mijne pogingen en die mijner vrienden, in 1874 van Weenen en van hier uit aangewend. Steeds ontving men in antwoord: "alle exemplaren zijn naar Indië verzonden."

Waar men ze echter in Indië zou hebben te zoeken, wanneer zelfs de schrijver, zooals hiervoren medegedeeld, 5 jaren na de uitgave er niets van wist, is eene moeijelijk op te lossen vraag.

Ik verwijl zoo lang bij deze zaak om duidelijk te doen uitkomen dat, als iemand in deze zaak een verwijt verdient, het in geen geval de reizigers der verschillende natiën zijn die de heer Kern aanhaalt, eu dat het allerminst mij dit verwijt kan treflen, die met den stand dier aangelegenheid even goed, ja zooals het wil toeschijnen, zelfs nog beter bekend is, dan de heer Kern, die hier den schoolmeester wil spelen, 
In geen geval is het moralisch geoorloofd weteuschappelijk materiaal aan de geleerde wereld te onthouden; is het echter toch geschied, zooals onbestrijdbaar in het voorleggende geval, zoo betaamt het niemand, nadat dit verborgen materiaal door anderen aan de duisternis en an de vergetelheid is ontrukt de wetenschappelijke wereld te willen doen gelooven, dit materiaal zij altoos toegankelijk geweest.

De heer Kern is zoo gelukkig de grammatikaalsche zamenstelling der mafoor:che taal zoo eenvoudig en de taal zelve zoo "helder" te vinden, dat het bem welligt zal verheugen te vernemen dat de taalkundige, de heer Hans Georg Conon von der Gabelentz, de waardige erfgenaam van dezen vermaarden naam, op het gebied der malayo-polynesische talen, zich sedert een jaar grondig met de mafoorsche taal bezig houdt, op grond der hem door mij medegedeelde zendelingsgeschriften en dat de hoop bestaat dat de uitkomsten dezer studiën bimnen een niet te groote tijdsruimte gepubliceerd zullen worden.

Men gelnove echter niet dat het onderwerpelijke gemakkelijk te doorgronden is. Wel is waar zou zulks niet moeijelijk vallen, wanneer men definicien accepteert zooals die van den heer Verhoefl', die de heer Kern mededeelt en goedkeurt, namelijk die, welke de schrijfwijze van het woord "Mafoor" betreft, en voor welke ik bij deze een woord zal bijpoegen.

De heer Verhoeff is van meening dat "Mefore" de naam des lands, "Noefoor" die der Papoeas van Doré, Mansinam en Ron is en deze uitspraak is den heer Kern voldoende, maar waarop zij zich grondt, wordt niet gezegd, en toch komt hierop alles aau.

Daar ik, toen ik met de Mafoorsche stammen verkeerde, die verschillende schrijfwijze des woords·bereids kende, zoo trachtte ik op de plaats uit den mond der Papoeas zelven de richtige uitspraak van het woord vast te stellen. De klinker der eerste syllabe wordt veeltijds onduidelijk geaspireerd, om zoo meer als die syllabe kort is , doch hoorde ik meestijds eerder "Mafoor" zeggen en accepteer op grond daarvan "Na".

"Noefoor" vindt zijn oorsprong in de "geleerde" redeneringeu der zendelingen, die het van "Doe", "wij beiden", en "foor", "vuur", afleiden: "Wij beiden hebben vuur." Duidende op dezen zin wordt hier ook eene "Sage" van den mafoorschen stam verhaald.

Doch volgens de persoonlijke verzekeringen des heeren van Hasselt is deze uitlegging eene reer twijfelachtige, en wordt 
"Noefoor" door de zendelingen alleen daarom bijbehouden, wijl het nu eenmaal door Geissler in de zendelingsgeschriften zoo is ingevoerd.

Mogt nu inderdaad Mafoor uit Noefoor ontstaan zijn, wat ja mogelijk is, zoo verklaart zich de verandering van $n$ in $m$ daardoor dat het volgende lipgeluid $f$ het gemakkelijker uit te spreken lipgeluid $m$ in den loop des tijds provoceerde. (Meest alle Zuidzee-eilanders beminnen de gemakkelijkheid bij het spreken).

De klinkerverschuiving van oe in $a$ laat zich gelijkerwijze verklaren. Ook zij heeft haar ontstaan aan de meerdere gemakkelijkheid voor den spreker te danken.

Maar hoe dit ook zij, welke innere waarschijnlijkheid biedt ons de verklaring van den heer Verhoeff? of welke autoriteit kan hij voor zich bijbrengen, dat door de Papoeas zelven dit onderscheid gemaakt wordt?

Bestond deze uitlegging des woords in werkelijkheid, voorzeker zou men ze mij hebben medegedeeld, daar ik, zooals bereids gezegd, met de zendelingen op N. Guinea meermalen over deze kwestie heb gesproken.

Ontvang, hooggeachte Heer! de verzekering mijuer bijzondere hoogachting.
Dresden, 24 Aug. 1875.
Dr. A. B. Meyer.

Directeur van het Koninkl. Museum van natuurlijke historie te Dresden."

\section{NASCHRIFT.}

"Toen ik in der tijd schreef dat de heer Dr. Meyer een paar, betrekkelijk belangrijke, bronnen voor de studie van 't Mafoorsch of Noefoersch verzuimd had op te geven, wist ik en kon ik niet weten dat hij ongeveer gelijktijdig, in een tijdens mijn schrijven nog niet uitgekomen geschrift, wel degelijk van die twee boeken gesproken had. Ik was dus, zoo men wil, voorbarig geweest. Bij die erkentenis voeg ik gaarne de verklaring dat niemand, tot nog toe, vollediger dan Dr. Meyer de bronnen voor de studie van genoemde Papoesche taal heeft opgegeven.

H. KERN." 
K OLONIA LE BI B I, IOG RA P H I E.

III.

Eene Afrikaansche bibliographie van J. GAY. - Eene bibliographie der oostersche talen, door P. A. M. Boele van Hensввовк. - Een gedenkschrift der Nederlandsch-Indische pers, door Mr. J. A. vaN DER ChIJs.

Ongetwijfeld is aan de koloniale bibliographische wetenschap eene goede toekomst verzekerd. Het ontbreekt althans niet aan ernst en goeden wil om haar grondig te beoefenen en daarvoor vruchtbaar te wezen. Werd er reeds menige loffelijke poging gedaan om op dat terreiu werkzaam te zij.jn, ook nu mogen wij wederom daarvan getuigen. De twee werken, waarvan de verschijning door ous reeds vroeger was aangekondigd, zagen 't licht; met de uitgave van een derde werden wij, weinige weken geleden, verrast. Aan de bespreking van dit drietal zij ditmaal ons bibliographisch overzicht gewijd.

Vangen we met het laatste werk aan, waardoor ook een uitgebreider terrein afgebakend wordt dan door de beide andere geschriften. De titel er van luidt: "Bibliographie des ouvrages relatifs à l'Afrique et à l'Arabie. Catalogue méthodique de tous les ouvrages français et des principaux en langues étrangères traitant de la Géographie, de l'Historie, du Commerce, des Lettres et des Arts de l'Afrique et de l'Arabie par Jean Gay. A San Remo (Italie), J. Gay et Fils. Paris, Maisonneuve \& Cie. 1875 , in $80 . "$

In 1842 gaf Ternaux-Compans zịjne "Bibliothèque Asiatique et Africaine" uit. Deze arbeid onvatte echter alleen de werken, die tot het einde der XVIIe eeuw verschenen waren. Daardoor kan, tot zekere hoogte althans, daarvan worden gezegd, wat in de "Préface" van 't werk, waarvan we den titel afschreven, aangeteekend wordt: "un pareil travail ne pouvait offrir d'intérêt qu'ì l'antiquaire, il en était dépourvu pour le reste du monde lettré." Intusschen was er niemand geweest, die de taak, op zoo verdienstelijke wijze door Ternaux-Compans begonnen, had voortgezet. Eene volledige Afrikaansche bibliographie bestond er tot dusver nog niet, welke leemte ook door het lid van het nationaal Instituut van Genève, den heer Jeau 
Gay werd ingezien. $\mathrm{Nu}$ zes jaren geleden, begon hij zijne krachten te wijden on daarin zooveel doenlijk te voorzien. Vrucht van dien arbeid is het werk, dat hij ons nu aanbiedt. In $312 \mathrm{blz}$, in 2 kolommen gedrukt, geeft hij eene lijst van de werken niet enkel over Afrika, mar ook over Arabië; inzonderheid zijn het frausche werken, die men er in aantreft; de titel zegt ons zelfs, dat men er al de fiansche geschriften in zal kumnen vinden. Een nauwkeurig onderzoek, dat we hieromtrent hebben ingesteld, heeft ons echter de overtuiging verschaft, dat de schrijver ons wel wat te veel beloofd heeft. Wèl zijn door hem inet zorg vele der voornaamste frausche bibliographieën geraadpleegd nevens enkele andere geschriften en lijsten van voorname boekmagazijnen en boekverkoopingen der laatste jaren, waaruit 't geen op Afrika en Arabië betrekking heeft is overgenomen. Zouderling echter dat op de lijst der door deu schrijver gebruikte geschriften ontbreekt de niet onbelangrijke "Catalogue général de la librairie Française pendant 25 ans (1830-1865) redigé par Otto Lorenz (Paris, 1867, 5 vols. in 8o)." Had de schrijver slechts daarmeê kennis gemaakt, ongetwijfeld zou hij dan zijne bibliographie gemakkelijk met nog enkele tientallen van in Frankrijk uitgegeven werken hebben kumnen vermeerderen.

Betreuren we deze betrekkelijke onvolledigheid, we maken er voorts den schrijver geen grief van, dat zijne lijst sober is met opzicht tot de werken, die, buiten Frankrijk, in Engeland, in ons vaderland en elders over Afrika en Arabië ziju verschenen. Immers reeds op 't titelblad worden we er aan herinnerd, dat we slechts "de voornamste geschriften in vreemde talen" zouden aantreffen. De geëerde bibliograaf schijnt uitsluitend fransche bromnen geraadpleegd te hebben; van 't gebruik althans van Engelsche of Duitsche bibliographieën blijkt ons nergens in zijn arbeid eenig spoor. Dat Nederlandsche boekenlijsten onvermeld zijn gebleven of dat men aan Nederlandsche geschriften over Afrika en Arabië, inzonderheid aan die over ouze voormalige bezittingen, de Kaap de Goede Hoop en de Kust van Guinea, geeu genoegzaam recht laat wedervaren, mogen we bejammeren, maar wij kunnen 't ons verklaren door de weinige bekendheid in den vreemde met 't geen hier te lande is en wordt verricht. Van daar dan ook dat wij in ons vorig opstel met sympathie gewargden van de poging

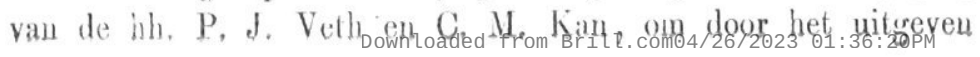


eener bibliographie van Nederlandsche boeken, brochuren, kaarten, enz. over Afrika eenig denkbeeld te geven van Nederland's aandeel aan de ontsluiering der geheimen van dit werelddeel. De inzage vau hun arbeid zij den heer Gay aanbevolen, niet slechts ter aanvulling van zijn werk, maar ook ter verbetering van de titels van enkele nederlandsche geschriften en artikelen, die daarin zijn opgenomen. 'Zoo vindt mẹ o. a. C. J. Jeckel voor C. A. Jeekel, van Bondyck Bastiaanse, voor van Boudyck Bastiaanse, terwijl wij in Miss Alexina Timué onze freule Alexandrina 'Time herkemen; enz.

Doch al behoort de arbeid vau den heer Gay aangevuld en verbeterd te worden, vooral wat 't Nederlandsch gedeelte betreft, het geleverde verdient toch aanbeveling zoowel on de zorg welke daaraan besteed is, als wegens de inrichting van den arbeid zelven. Met nauwkeurigheid zijn verreweg de meeste titels opgegeven 1; telkens wordt daarbij vermeld, aan welke bron zij ontleend zijn; voorts tal vau bibliographische bijzonderheden, terwijl bij een overgroot deel der schrijvers, wier werken worden opgegeven, biographische aanteekeningen zijn gevoegd. Ook zal men er niet te vergeefs cene opgave zoeken van de artikelen, welke sommige auteurs of reizigers in tijdschriften, mengelwerken en voorname dag- en weekbladen hebben geplaatst.

De vermelding van een en ander geschiedt in systematische orde. De 15 eerste bladzijden worden ingenomen door de geschriften die over Afrika en Arabië handelen, waarop die volgen over Afrika in 't algemeen en zijn verschillende staten. In het derde tot het vijfde hoofdstuk vindt men de werken over Noord-, Midden- en Zuid-Afrika, terwijl 't zesde of laatste wordt ingeruimd voor die, welke over Arabië handelen; het geheel bevat 3696 titels. Geeft reeds de systematische indeeling gelegenheid om aanstonds een overzicht te erlangen van al wat er op verschillend gebied over Afrika en Arabië is geschreven, het zoeken naar den een of anderen schrijver wordt vergemakkelijkt door de alphabetische lijst van de namen der auteurs, die tegelijk met een alphabetisch register van de plaatsnamen

1 Hier en daar treft men wel een gansch onvolledigen titel aan; zoo o. a., om slechts een enkel voorbeeld te noemen, deze opgave: «Fressange. A écrit sur Madagascar, dans les Annales des Voyages.n De vraag rijst aanstonds op: welke Annales worlen hier bedoeld? in welk deel en in welk jatr? 
aan 't einde van 't werk wordt toegevoegd. Wij twijfelen er dan ook niet aan of deze arbeid des heeren Gay zal goede diensten bewijzen aan allen, wier studiën Afrika of Arabië tot ouderwerp hebben.

Een niet minder welkom hulpmiddel, doch op gansch ander en niet minder uitgebreid terrein, werd ons onlangs door een jeugdig bibliograaf aangeboden. We bedoelen: "De beoefening der Oostersche talen in Nederland en zijne overzeesche bezittingen 1800-1874. Bibliographisch overzicht door P. A. M. Boele van Hensbroek. Bekroond door, en uitgegeven op last van de Vereeniging ter bevordering van de belangen des Boekhandels. Leiden, E. J. Brill, 1875. 90 gr. 4 . blz. en 17 blz. register."

Dit werk verscheen den 8sten Februari l.l. en maakte 't eerste gedeelte uit van de "Feestgave ter gelegenheid van het driehonderdjarig bestaan der Leidsche Hoogeschool" door de firma E. J. Brill, te Leiden, met ongeëvenaarde liberaliteit bezorgd, aan Curatoren der Leidsche Hoogeschool opgedragen, doch helaas! niet in den handel verkrijgbaar gesteld. Een der verdienstelijke kweekelingen dier Universiteit, de heer W. Christ. Rittershausen, van wiens hand 't tweede deel der Feestgave is, en die in eene daaraan toegevoegde belangrijke voorrede een waardig woord van hulde brengt aan de Leidsche boekdrukkers, wier namen op zooveel oostersche uitgaven prijken, deelt ons omtrent 't ontstaan en de uitgave van des heeren Boele's werk meê, dat het oorspronkelijke plan was om ter opluistering van 't Academiefeest "eene geschiedenis te schrijven van de opkomst en ontwikkeling der drukkerijen in Leiden, een overzicht te geven van alles wat zij voor de oostersche talen hebben gedaan en daaraan toetevoegen eenige bladzijden arabischen tekst met eene hollandsche vertaling. De Firma Brill vreesde echter, wanneer zij aan dat plan uitvoering gaf, zich onwillekeurig aan zelfverheffing te zullen schuldig maken, en besloot dus liever iets anders daarvoor in de plaats te stellen. De "Vereeniging van den Boekhandel in Nederland" had een antwoord op eene prijssvraag bekroond, een "linguistische catalogus van oostersche werken die sedert het begin dezer eeuw in Nederland en de Indiën het licht hebben gezien", vervaardigd door den heer Boele van Hensbroek, en deze "catalogus", daartoe welwillend afgestaan, leende zich voortreffelijk tot het doel, terwij] hij het dubbele yoordeel bezat, dat hij niet alleen 
nuttig was, maar ook de klip deed vermijden waarop men gevaar liep te stooten.

Gelukkiger keuze kon men zeker niet gedaan hebben. Immers bij het 3 e jubilé der Leidsche Hoogeschool - wij zeggen 't met den heer Fred. Muller, die aan de Feestgave der Leidsche Boekhandelaren eene waardige hulde bracht in t Nieuwsblad voor den Boekhandel van Vrijjdag, 19 Februari 1875, no. 14-, legt dit werk een eervol getuigenis af van den bloei der Oostersche talen in deze eeuw in ons land. Zeer terecht is aan de Leidsche Hoogeschool dit werk door deze firma als Feestgave aangeboden, omdat voornamelijk door deze Universiteit de studie der Oostersche talen in ous land bevorderd" is, en de private oostersche drukkerijen van Erpenius en Golius, in de eerste helft der 17e eeuw gesticht, nu vervangen zijn door de geheel éénige oostersche drukkerij der firma Brill." Intusschen "hoe fraai die Bibliographie nu ook in die Feestgave prijkt, zoo zou ze toch voor de wetenschap verloren zijn, indien ze daarin verborgen bleve." Gelukkig heeft men daarvan eene afzonderlijke uitgave bezorgd en in den handèl gebracht, welke thans voor ous ligt.

Hoewel nu als een feestgeschenk aangeboden op een wetenschappelijk feest, werd zij echter door den bewerker zelven in de eerste plaats voor den boekhandel bestemd, voor practisch gebruik vervaardigd. Zij omvat, gelijk reeds uit den titel blijkt, slechts de oostersche geschriften tusschen 1800 en 1874 uitgegeven. Wanneer ook de werken, vóor onze eeuw verschenen, daarin eene plaats hadden verkregen, zou hij - de heer Rittershausen zeide 't reeds - daardoor in belangrijkheid veel hebben gewonnen; doch betreuren wij met hem hun gemis, in de hoop tevens dat de heer Boele ook daaraan eens zijne krachten zal wijden om onze oostersche bibliographie volledig te maken, voor 's hauds echter aanvaarden wij met erkentelijkheid 't geen door hem geleverd is, "zoowel als eene bijdrage voor een algemeenen systematischen catalogus van in Nederland verschenen werken, als voor eene geschiedenis van de beoefening der oostersche talen."

Onder oostersche talen rekent de schrijver de Semitische en de Arische talen zoowel als het Chineesch, het Japansch, het Farorlangsch (Formosaansch) en de talen van den indischen archipel, terwijl als aanhangsel nog 't Egyptisch komt. Aangaande de grenzen, waarbinnen hij zich heeft beperkt, wordt

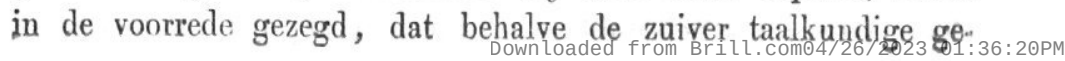


schriften niets is opgenomen, dan de werken over Mohamedaanschen godsdieust en recht; volgens uitspraak der meest bevoegde beoordeelaars is de studie dier werken toch onmisbaar voor den beoefenaar o. a. der Maleische en Javaansche talen. Dat de grens tusschen bijbelsche taalkunde en godgeleerdheid dikwijls zeer moeielijk te bepalen was, is duidelijk; de bewerker hoopt er in geslaaga te zijn de grenslijn zuiver te trekken."

Wij betwijfelen 't zeer of de heer Boele wel gebleven is binnen de grenzen, die hij zich gesteld heeft. Immers nevens zuiver taalkundige geschriften en die over islamitischen godsdienst en recht vonden we in zijne bibliographie ook tal van werken van een anderen aard opgenomen. Om ons alleen tot onzen archipel te bepaler, troffen we er o. a. geschriften aan over aardrijkskunde, eene beschrijvíng der Koen's feesten ten jare 1869, eene beschrijving van Batavia door Raden Ario Sastro-darmo, eene van Nederlandsch-Indië, eene handleiding voor den Javaanschen landbouwer, een werkjen over het batikken van Javaansche kleedjes, eene beschrijving der tentoonstelling van nijheid, enz. te Batavia, een leerwijze voor de exercitie met het kanon ì drie pond à pivot aan boord der Gouvernements-kruisbooten, zelfs een kookboek. Al te gader werken, waarvan de heer Boele o. i. de opname niet wel zal kumnen rechtvaardigen, waar hij op den voorgrond gesteld heeft om in zijn arbeid niets op te nemen dan wat onder de beide aangegeven rubrieken kan worden gebracht. Of zou wellicht de opgave van de door ons angeduide geschriften, die telkens onder 't hoofd "teksten en vertalingen" voorkomen, moeten dienen om duidelijk in 't licht te stellen de vaardigheid en bekwaamheid om zich onder meer ook over de bedoelde onderwerpen gemakkelijk in de Javaansche en Maleische talen uit te drukken?

Maar wat hiervan zij, voor het feit der opname ook van werken buiten de vakken der taalkunde, god- en rechtsgeleerdheid, zijn wij den schrijver dankbaar; 't kan toch strekken om ous den omvang eener bibliographie der oostersche talen te leeren kennen. Dat de bijdrage nog onvolledig is, de schrijver erkent 't zelf in zijne voorrede; "t kan niemand duidelijker zijn dan den vervaardiger ". Ook is volledigheid op bibliographisch terrein zelden bereikbaar, en ik mocht mij niet vleien dat de lijst des heeren Boele eene uitzondering op dien regel maken zou. Maar toch mag na eenig onderzoek daarvan de getuigenis worden af-
Down 
gelegd, dat het ontbrekende van geringen omvang is, vergeleken bij 't opgegevene.

Zie hier slechts een paar onzer aanteekeningen.

Terwijl we de afdeelingen: Semitische en Arische talen, 't Chineesch, Japansch en Egyptisch voor 's hands lieten rusten, viel onze aandacht al dadelijk op de Favorlangsche taal. Bij de vermelding van de uitgaaf van Happart's Woordenboek bevreemdt 't ons geen gewag te zien gemaakt van de Engelsche vertaling: "Dictionary of the Favorlang dialect of the Eormosan language, bij Gilbertus Happart, written in 1650. Translated from the Transactions of the Batavian Literary Society, bij W. H. Medhurst. Batavia, printed at Parapattan, 1840, 383 p." - In de onmiddellijk daarop volgende afleeling: "Talen van den indischen archipel. Algemeene werken. Monographien." missen wij ongaarne, onder meer, nevens de vermelde necrologieën, J. Wap's levensbericht van Dr. S. Keyzer, geplaatst voor den verkoopcatalogus zijner boeken, met portret; Meinsma's overzicht van 't leven van Mr. I). Koorders, in diens opstel: "Iets uit de nalatenschap van Mr. D. Koorders", waarin tevens vele bijzonderheden voorkomen omtrent de beoefening van het Soendaneesch; ook de opgave van Koorders' brochure: "Taalen Bijbelmishandeling. Aan het Bestuur van de Nederlandsche Zending vereeniging", uitgegeven bij Kemink en Zoon , te Utrecht, die de heer Boele niet schijnt gekend te hebben, terwijl hij zich alleen vergenoegt te wijzen op de Rapporten des heeren Koorders over Soendaneesche lees- en volksboekjes, zonder eenige verdere aanteekening zijnerzijds.

Met betrekking tot 't opgegevene in de afdeelingen "Maleisch N en "Javaansch" veroorloof ik mij alleen de opmerking te maken, dat 0 . a. de verzameling behoorende aan het Indisch Leesmuseum of de bibliotheek van de gemeenteinstelling van onderwijs in de Indische taal-, land- en volkenkunde te Delft aan den heer Boele goede diensten zou bewezen hebben. Althans door de bijzondere welwillendheid vau den heer Dr. A. W. T. Juynboll zijn we in staat gesteld meê te deelen, dat slechts enkele der in de bibliographie genoemde indische werken aan die verzameling ontbreken, terwijl 't ons bleek, dat zij bovendien nog een groot aantal nominers bevat, welke wij in de opgaaf van den heer Boele niet hebben gevonden. Het zou niet alleen te dor zijn, maar ons ook te ver van den weg voeren, zoo wij de lijst dier ontbrekende nommers hier wilden mededeelen. We stellen ze intusschen gaarne 
ter beschikking van den geëerden schrijver, die tevens zeker met genoegen zal vernemen, dat onder meer belangrijks daarbij ook voorkomt een catalogus van 't geen ter landsdrukkerij verschenen is, onder den titel: "Daftar kitab-kitab jang di dapati di kantor tjitak Goubernement (1 Nov. 1872), " met den inhoud waarvan 't door hem opgegevene kan worden vergeleken.

Zal de heer Boele byj kennisneming van dit een en ander zijn bibliographisch overzicht aanmerkelijk kunnen vermeerderen, met voorbijgang der andere afdeelingen daarvan trof ons bovenmate de-soberheid met opzicht tot de talen van Nieuw-Guinea. Het boekje van J. T. van Hasselt, de beide drukken der Noefoorsche vertaling van het Evangelie van Markus, de 4 stukjes van het spel- en leesboekje, voor de scholen op Nieuw-

- Guinea, J. G. Geissler's vertaling van F. L. Zahn’s Bijbelsche geschiedenissen, de Psalmen en Gezangen in de Noefoorsche taal: - al deze uitgaven, vanwege de Utrechtsche Zendingsvereeniging, door Kemink en Zoon, te Utrecht bezorgd, niet tal van jaren geleden, maar gedurende 1867-1871, schijnen aan zijne aandacht te zijn ontsnapt.

Maar genoeg. Het meegedeelde, dat wij gemakkelijk zouden kunnen vermeerderen, moge hem een bewijs zijn van onze belangstelling in zijn arbeid en zij hem tevens welkom ter aanvulling en verbetering daarvan, zoo, wat wij hem gaarne zouden toewenschen, eene hernieuwde uitgaaf mocht worden gevorderd. Maar dan worde tevens overwogen in hoever ook be. hartiging verdient 't oordeel, dat we over 't werk uitgesproken vonden in het Algemeen Dagblad van Nederlandsch-Indië van Woensdag, 23 Juni ll. no. 144. "Het is zuiver bibliographisch", heet 't daarin, "niet oordeelkundig, zoodat belangrijk en onbelangrijk door elkander staat. Echter maken een overzicht van den inhoud en een alphabetisch register het zoeken gemakkelijk, en wie geene of slechts eene kleine eigen boekerij bezit, vindt hier met een oogopslag allerlei nuttige aanwijzingen in een kort bestek bijeen. Wat men er echter niet uit zien kan, is, in welk opzicht de studie der Oostersche talen door Nederlandsche geleerden vooruitgebracht is. Daarom zou het wenschelijk zijn dat een man van het vak uit dezen catalogus al de eigenlijk gezegd wetenschappelijke werken bijeenzocht en daarvan een in het Fransch of Duitsch of Engelsch geschreven vergelijkend overzicht uitgaf. Dit zou voor onze geleerden zelven het aangenaam gevolg kumen hebben dat hun arbeid in het buitenland 
meer bekend werd, en teveus zou het nuttig zijn voor onze jongelieden, die anders gevaar loopen door het uitsluitend raadplegen van afgeleide vaderlandsche bromnen, veel tijd te verliezen. Het Oostersch is zulk een kosmopolitisch vak van studie, dat de kennis van hetgeen Nederland en zijn overzeesche bezittingen in de laatste vijf en zeventig jaren daaraan gedaan hebben, hoogsteus als inleiding waarde bezit”.

Van 't werk des heeren Boele tot dat van Mr. J. A. van der. Chijs is de stap niet groot. Reeds vroeger koudigden wij de voorgenomen uitgave daarvan aan; eerder dan wij konden verwachten, kregen wij het in handen, prijkend met dezen bescheiden titel: "Proeve eener Nederlandsch-Indische Bibliographie $(1658-1870)$ door Mr. J. A. van der Chijs, Phil. Theor. Mag. Litt. Hum. Doct. Uitgegeven door het Bataviaasch Genootschap van Kunsten en Wetenschappen. Batavia, Bruining \& Wijt. 's Hage, M. Nijhofl, 1875, in gr. so. (1)."

Steller dezer regelen mag het niet ontveinzen dat hij liever deze Proeve onbesproken zou hebben gelaten, met 't oog vooral op 't bekende feit, dat hij zelf sinds jaren aan de samenstelling van een soortgelijken arbeid bezig is, waardoor men, zoo soms zijn oordeel min gunstig mocht zijn, wellicht geneigd zou wezen 't toe te schrijven aan eene niet genoegzame mate van oupartijdigheid. Het werk is intusschen te belangrijk, dan dat hij zich verantwoord zou achten, zoo hij zich door die beschouwing let verleiden om daarover in dit koloniaal bibliographisch overzicht het stilzwijgen te bewaren. Te minder mocht hij daartoe vrijheid vinden, waar men daarover reeds een oordeel heeft geveld, dat naar zijne bescheiden meening niet alleszius juist en billijk kan heeten.

Het doel, dat de heer van der Chijs beoogt, is om ons zooveel doenlijk voor te lichten omtrent hetgeen de Indische pers in deu loop des tijds sedert de helft der zeventiende eeuw tot op onzen tijd heeft geleverd. Onder Nederlandsch-Indische bibliographie verstaat hij niet eene zooveel mogelijk volledige

(1) Een merkwaardige bijdrage ter beoordeeling van de wijze, waarop men partij trekt van de verbetering onzer communicatie-middelen, is het feit dat dit werk, dat reeds in 't begin van Juni in Indië uitgegeven en besproken werd, in October nog niet hier te lande verkrijgbaar is; ook de wetenschappelijke instellingen, waarmee het Bataviaasch Genootschap $\operatorname{van} K$. en W. een letterkundig verkeer onderhoudt, hebben het nog niet mogen ontvangen. 
koloniale bibliographie in haren geheelen omvang, zoodat daaronder vallen moet wat de pers in Nederland over ons overzeesche rijk en wat zij in Indië zelf heeft geleverd; evenmin bedoelt hij een opgaaf van de vruchten der pers in de gewesten, zooals Ceylon en andere, welke eertijds tot ons rijk hebben behoord; alléén op ons Indië, zooals het tegenwoordig is, heeft hij 't oog en wenscht hij eene bijdrage te leveren, waaruit men een deel van 't intellectueele leven aldaar zou kunnen kennen.

Vasthoudend aan deze enge grenzen, die hij zich gesteld heeft, geeft de geëerde schrijver ons eerst in chronologische orde een nomenclatuur van de hem bekende drukwerken der $17^{\mathrm{e}}, 18^{\mathrm{e}}$ en $19 \mathrm{e}$ eeuw; daarna van die, welke geene dagteekening dragen, waarop een overzicht gegeven wordt der Ned. Ind. nieuwsbladen met een lijst van Ned. Ind. drukkers en uitgevers, terwijl eindelijk op dit vijftal rubrieken een paar onuitgegeven officiëele stukken, met 't behandelde onderwerp in betrekking staande, als Bijlagen volgen. Een en ander wordt verrijkt met een alphabetisch register en een schat van aanteekeningen en historische bijzonderheden, die voor eene geschiedenis van de Indische drukpers niet van belang ontbloot en meerendeels ontleend zijn aan onuitgegeven stukken, door den heer van der Chijs in de Bataviasche archieven en elders, geraadpleegd.

De heer Gualth. Kolff, die van dit werk eene uitvoerige ankondiging plaatste in het Nieuwsblad voor den Boekhandel van den 16 Juli $1875, \mathrm{n}^{0}$. 56 , en tevens aan de hand en naa aanleiding daarvan een niet onbelangrijk en beknopt historisch overzicht van de Indische pers gaf, is uitbundig in zijn lof. $\mathrm{Hij}$ noemt het "een waardig monument, gewijd aan de drukpers en boekhandel in Ned. Indië" ; in verband met de schier onoverkomelijke bezwaren en moeielijkheden aan de samenstelling verbonden, " eene proeve even stout als welgeslaagd"; een " arbeid boven zijn lof verheven, en die ongetwijfeld door iederen bibliograaf in Nederland met graagte en erkentelijkheid zal worden ontvangen, trots al het ontbrekende dat aan deze proeve misschien moge aankleven ", terwijl "de firma Bruining \& Wijt door eene keurige typographische uitvoering gezorgd heeft, dat haar naam waardiglijk prijke aan den voet van dit gedenkschrift der Nederlandsch-Indische pers".

Toen de heer Kolff, te Leiden, deze lofrede schreef, konden hein de nummers 132,139 en 146 van het Algemeen Dagblad 
van Nederlandsch-Indië van 9,16 en 25 Juni 11 nog niet bekend zijn. Daaruit zou hij hebben kunmnen ontwaren, dat zijn enthusiasme lang niet gedeeld zou zijn geworden door den schrijver van het in 't eerstgenoemde nummer van gemeld Dagblad voorkomend leadingartikel. Het nieuwe werk van den Indischen Schoolinspecteur heet daar " eene mislukte proeve", die men "Inet weerzin" aankondigt. "Het is niet alleen een monument dier klemsteedsche ijdelheid, welke alles wat in haar kersspel voorvalt belangrijk vindt, maar mist zelfs de verdienste van toonbaar volledig te zijn. De bezitters van den catalogus der bibliotheek van Prof. Millies, verleden jaar door Maissonneuve en Cie te Parijs uitgegeven en gratis of voor weinige stuivers overal te bekomen, vinden daarin behalve een schat van oostersche werken, een aantal bij uitzondering merkwaardige in $\mathrm{N}$. I. gedrukte boeken en boekjes vermeld, van wier bestaan de schrijver der Proeve geene kennis heeft gedragen. Zes te Colombo gedrukte Hollandsche geschriften uit de tweede helft der vorige eeuw, waaronder de vermaarde Triumph der Waarheid van den bekeerden Cingalees Filippus de Melho, worden bij hem gemist, gelijk hij in het algemeen zwijgt over alles wat ter drukkerij van de Compagnie op Ceylon is uitgegeven. Op zijne lijst der oudere en nieuwere Indische drukkerijen staat de Colombosche zelfs niet voor memorie uitgetrokken. Twee in 1864 te Makassar gedrukte Boeghinesche geschriften van Dr. Matthes ontbreken in de Proeve; desgelijks een in 1842 te Batavia gedrukte Hollandsch-Engelsch-Javaausche woordenlijst van Bruckner, een in 1847 te Batavia gedrukt Javaansch gedicht van F. Winter, een Maleisch evangelie van Johannes in 1823 te Benkoelen verschenen, een in 1834 te Ambon gedrukt christelijk leerboekje van Gericke, een in 1839 te Batavia verschenen Maleisch en Chineesch boekje van godsdienstigen aard, dat aan Medhurst wordt toegeschreven, de fabelen en vertelsels van Lokman en Bidpai door Gonggrijp (Batavia, 1866), vijf preeken van Medhurst in het Maleisch met Arabische karakters (Batavia, 1841-42), eene Maleische vertaling der Psalmen in 1827 te Padang gedrukt, een aardrijkskundig handboekje voor de Inlandsche scholen op Sumatra (Benkoelen, 1826), het Nieuwe Testament in het Maleisch door H. C. Klinkert (Samarang, 1861-63).

"Doch", zoo vervolgt onze Recensent, "het is eene betrekkelijk geringe zaak dat in de Proeve stukken ontbreken, die 
men in den Franschen catalogus voor het grijpen heeft. Hetgeen de schrijver geeft is ruim zoo ergerlijk als hetgeen hij onthoudt. Vijfendertig malen hebbẹn wij bij hem de werken van het Bataviaasch Genootschap vermeld gevonden (alleen de cijfers der deelen wel te verstaau, want de titels worden niet opgegeven); zeven en twintig malen de Javasche Courant, negentien malen den Java-Bode, dertien malen het Bataviaasch Handelsblad, andere bladen en tijdschriften en jaarboeken naar evenredigheid. Op de wederverschijningen van den regeeringsalmanak hebben wij geen oog kunnen houden, evenmin als op de vastenbrieven van Msgr. Vrancken, of de tekstboekjes van Fransche operas, of de reglementen van societeiten op Java en de buitenbezittingen. Catalogussen van boekenvendutiën ontbreken (rok dan wanneer eene enkele maal de naam van den verzamelaar eene uitzondering had moeten doen toelaten), doch voor het overige is er tussehen 1659 en 1870 in Nederlandsch Indië niets gedrukt en den schrijver der Proeve onder de oogen gekomen of van hooren zeggen bekend geworden, het doet er niet toe, hoe oubelangrijk en nietig, - of $\mathrm{Mr}$. van der Chijs heeft er aanteekening van gehouden. Gelijk van zelf spreekt, komen onder dat scheurpapier een aantal bibliographische zeldzaamheden voor; doch het zijn zeldzaamheden als die, waarvan Brunet in de voorrede van zijn Manuel du $\mathbf{L i}$ braire geestig zegt, "qu'elles sont d'une nullité si complète que personne ne se soucie de les acquérir; livres rares, mais sans intérêt, dont on peut dire avec raison que'les lecteurs sont encore plus rares que les exemplaires." Al dat uitschot, al die prullen, de andacht dubbel onwaardig omdat zij in hun geheel niet de minste voorstelling geven van hetgeen werkelijk in den loop des tijds over Indië verschenen is, vindt men in de Proeve vermeld. En nog is de schrijver over zijn eigen arbeid niet voldaan. Hij had iets volledigers willen leveren, een "standardwork"; en aan het slot zijner voorrede klaagt hij, dat het met de belangstelling der $\mathrm{N}$. Indische uitgevers in de $\mathrm{N}$. Indische bibliographie nog treurig gesteld is.

"Het denkbeeld alleen dat $\mathbf{M r}^{\mathbf{r}}$. van der Chijs aan de mogelijkheid van een standaardboek gelooft, waar hoogstens spraak kan zijn van het bijeenlezen van eenige schrale koloniale aren, half bij toeval ver van het moederlandsche bouwveld terecht gekomen, had de direktie van het Bataviaasch Genootschap, die het boek uitgaf en daaraan minstens een par duizend gulden 
verspilde, eene waarschuwing moeten zijn. Hollandsche boeken te Colombo, Javaansche te. Serampore, Maleische te Singapore, te Malakka of weleer te Benkoelen gedrukt, vallen niet, zelfs niet als aanhangsel, in het kader eener N. I. bibliographie naar de boekhouders-opvatting van den schrijver der Proeve. Nog veel minder schenkt hij aandacht aan hetgeen in vroeger en later tijd te Amsterdam, te Rotterdam, te Haarlem, te Leiden en over het algemeen in Nederland of in Europa gedrukt is. Alleen wat in het tegenwoordig Nederlandsch-Indië het licht aanschouwde heeft waarde voor hem, en daarin gelijkt hij den koster der Nederlandsche dorpskerk, die weinig dingen op aarde bezienswaardiger vond dan het door den schoolmeester der plaats met de pen geteekend psalmen en gezangenboek, bij de openbare godsdienstoefeningen in gebruik, woorden, balken en noten in kluis. Op zolke grondslagen en binnen zulke grenzen is geene voor de wetenschap vruchtbare bibliographie van N. I. bestaanbaar. Een armoedige inhoud wordt door praal van wetenschappelijke termen niet vergoed. Vochtigheid en insekten, dat weet ieder, voeren in Indië strijd tegen de boeken, doch den schrijver der Proeve is die taal te eenvoudig. Hij zegt: "N. I. is een land, waar het bewaren van boeken door climatologische en entomologische invloeden zeer belemmerd wordt." Wij gelooven gaarne dat het voor de leden der direktie onderling moeielijk is, elkanders ter uitgave aangeboden werk te kritiseren. Eeu indiskreet medelid heeft daardoor tegenover de algemeene welwillendheid vrij spel. Doch mag ter wille van zulke beweegredenen de algemeene kas van het Genootschap blindelings worden aangesproken? De catalogussen van Mr. van der Chijs, als wier voortzetting men zijne Ned. Indische bibliographie te beschouwen heeft, zijn van dien aard dat zij even goed door een welonderwezen inlandsch kind hadden kunnen samengesteld worden " .

De Recensent liet 't niet bij deze reeds zoo scherpe kritiek. Men scheen hem daarover aangesproken te hebben; althans in ㄲo. 138 van 't Alg. Dagblad, eene week later verschenen, deelt hij ons meê, dat, terwijl hij de onvolledigheid der bibliographische Proeve van Mr. van der Chijs "een betrekkelijk ondergeschikt punt " noemde, anderen evenwel van die bijzaak eene hoofdzaak hẹbben gemaakt en de volledigheid gehandhaafd. Van daar dat hij hun tot nadere anbeveling van het door hem geschrevene in 't gemeld nummer 't lijstje aanbood der tekort- 
komingen gelijk het hem daarbij gedieud heeft ( $\left.{ }^{1}\right)$, na de meêdeeling waarvan hij nog dit bijvoegt: "Overigens stemt ons gevoelen over de soort van geleerdheid, die wij eene openbaring van kleinsteedsche ijdelheid noemden, geheel overeen met hetgeen Prof. Cobet daarvan op 8 Februari jl. schertsend zeide: "L'érudition est une chose terriblement dangereuse. Quand on

1 (In onze aankondiging der bibliographische Proeve van Mr. van der Chijs noemden wij hare onvolledigheid een betrekkelijk ondergeschikt punt en stonden er niet langer bij stil dan noodig was. Nu evenwel anderen van die bijzaak eene hoofdzaak maken en de volledigheid handhaven, geven wij het lijstje der tekortkomingen gelijk het ons bij het schrijven ge diend heeft :

De Algemeene Sendbrieven der H. Apostelen, Colombo 1776. - Mallabaarse Catechismus, Colombo 1739. - Singhaleesch formulier-boekColombo 1774. - J. Ph. Wetzelius, Singhaleesch Belijdenisboekje, Colombo 1742. - Kort ontwerp van de Leere der Waarheid, Colombo 1744. $\mathrm{Ph}$. de Melho, Triumph der Waarheid, Colombo 1753. - B. F. Matthes, Boegineesch Heldendicht, Makassar 1864. - B. F. Matthes, Boegineesch Chrestomathie, Makassar 1864. - Aug. Hardeland, Pira-Pira enz., Borneo 1845. - Aug. Hardeland, Due tempare enz., Borneo 1845. - Aug. Hardeland, Surat hapan adjar membasa, Kaapstad 1846. - Pira-Pira enz., Batavia 1843. - Bruckner, Proeve eener Javaansche spraakkunst, Serampore 1830. - Bruckner, Javaansch traktaatje, Serampore 1826. Bruckner, Godsdienstige verhandeling in het Javaansch, Serampore 1854. - Bruckner (?), Een kort vertoog der christelijke godsdienst in het Javaansch, Serampore, z. j. - Bruckner, hetzelfde vertoog in steendruk. Banjermasin 1851. - Bruckner, Nieuw Testament in het Javaansch, Serampore 1829. - F. Winter, Romo, naar de bewerking van Joso Dhipoero, Batavia 1847. - W. Luyke (?), Kort begrip der christelijke leer, in het Lettisch, Batavia 1836. - Evangelie van Mattheus, Maleisch met Arabische karakters, Singapore, z. j. - Evangelie van Johannes, Maleisch met Arabische karakters, Benkoelen 1823. - Bunyan's Reize naar de eeuwigheid, Maleisch, Singapore 1854. - Gericke, christelijk leesboekje in het Maleisch met Latijnsche karakters, Ambon 1834. Medhurst (?), Christelijk traktaatje in het Chineesch en Maleisch, Batavia 1839. - Verkorte geschiedenis van Mozes in het Maleisch met Arabische karakters, Malakka 1841 (?). - Honderd zestien Maleische gezangen met Arabische karakters, Singapore z. j. - Maleisch leesboek met Latijnsche karakters, Singapore 1845. - J. R. P. F. Gonggrijp, Fabelen van Lokman en Bidpai, Batavia 1866. - Medhurst, Vijf Leerredenen in het Maleisch, met Arabische karakters, Batavia 1841. - Het Boek der Psalmen in het Maleisch, Padang 1827. - Katechismus der Aardrijkskunde voor de Inlandsche scholen op Sumatra, Benkoelen 1826. - Zes christelijke leerredenen in het Maleisch met Arabische karakters, Singapore z. j. Maleische verhaaltjes voor kinderen, zes afleveringen, Singapore 1848. H. C. Klinkert, Nieuw Testament in het Maleisch met Latijnsche karakters, Samarang 1861-63. - Th. Thomsen, Engelsch-Maleische woordenlijst,

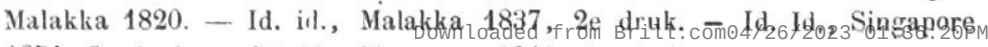
1854, 3e druk. - Id, id, Singapore 1861, 4e druk. via free access 
n'y preud pas garde, et bien garde, ce grand savoir, cette vaste érudition, étouffent tout doucement, tout doucement, le bon gout d'abord et le bon sens ensuite; il reste alors ce que le Français né malin appelle un savant en $u s$, c'estàdire - je n'ose presque introduire le mot - un imbécile, qui sait immensément de choses, excepté ce qu'il faut absolument et avant tout savoir".

De lijst intusschen vau de werken, die in de bibliographische Proeve van Mr. van der Chijs zouden ontbreken, scheen iet wat haastig te zijn opgemaakt. 'Tot revisie daarvan zag men zich dan ook weldra genoodzaakt; men gaf ze in no. 146 van 't meergemelde Dagblad van Vrijdag, 25 Juni 1875, waarbij men, nevens eene beperking van de vroeger als, ontbrekend opgegeven titels, tevens eene verbetering gaf van zijn oordeel over de Proeve, waarbij echter niets teruggenomen werd van hetgeen overigens ter veroordeeling daarvan in het eerste artikel was geschreven. Het is niet onbelangrijk kennis te nemen van de nadere beschouwing, welke wij hieronder in haar geheel opnemen (1).

1 "In ons nummer van 16 dezer gaven wij de titels van een veertigtal in Indië gedrukte boeken en boekjes, door ons in den meermalen genoemden catalogus van Maisonneuve en Co. aangetroffen en in de bibliographische Proeve van Mr. van der Chijs vruchteloos gezocht. Thans makt men ons opmerkzaam, dat 15 van die 38 geschriften werkelijk bij Mr. van der Chijs te vinden zijn, en wel 9 daarvan op bladz. 266 vgg. der Verbeteringen. Twee andere, die bij Maisonneuve het jaartal 1864 dragen, staan bij Mr. van der Chijs het eene op 1858, het andere op 1863. Van één, door M. vermeld als te Banjermasing gesteendrukt, wordt zonder opgaaf van redenen het bestaan twijfelachtig genoemd. Nog een is te vinden onder 1847: werken van het Bataviaasch Genootschap. Een ander (het $\mathrm{N}$. Testament van H. C. Klinkert) staat bij Mr. C., zonder Klinkert's naam, op twee verschillende jaartallen (de eerste helft op 1861, de tweede op 1863). De fabelen van Lokman en Bidpai, door Mr.van der Chijs onder den naam van den bewerker Gonggrijp gebracht, vindt men bij M. onder die der oorspronkelijke samenstellers. Omtrent het boekje Pirä Pirä, eindelijk, dat in 1843 hier ter stede gedrukt werd, hebben wij ons vergist, aangezien dit door Mr. van der Chijs onder aan bladz. 74 zijner Proeve genoemd wordt.

Het vergelijken dezer opgaven met de vroegere heeft ons tot de overtuiging gebracht, dat de heer van der Chijs den catalogus der bibliotheek van Prof. Millies, dien Maisonneuve drukte, aanvankelijk niet gekend, maar zonder er naar te verwijzen, bij het opmaken zijner lijst van Verbeteringen gebruikt heeft. Hetzelfde deed hij ten aanzien van het Bibliographisch overzicht van Boele van Hensbroek, dat wij eergisteren aan-

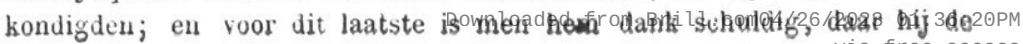


Men vergeve ons de uitvoerigheid, waarmeê wij na de uitbundige lofrede de scherpe kritiek over 't werk des heeren van der Chijs hebben medegedeeld. Met geen van beide kunnen wij ons onvoorwaardelijk vereenigen; hoewel er in beide veel is, dat niet onjuist kan worden genoemd. Echter kunnen wij ons niet ontveinzen, dat de schrijver der lofrede ons voorkomt meer bevoegd te zijn om op bibliographisch terrein mede te spreken dan de steller van de scherpe veroordeeling. Terwijl

overgenomen titels zuiverde van drukfouten. De heer Boele van Hensbroek namelịk heeft ondernomen de beoefening der Onstersche talen in Nederland en zijne Overzeesche bezittingen te schetsen, zonder kennis van eene of meer dier talen te bezitten; en men begrijpt licht dat die omstandigheid, zoo niet juist een entomologischen of climatologischen, dan toch in het algemeen een storenden invloed op de nauwkeurigheid heeft uitgeoefend.

Één ding prijzen wij echter in het boek van dan heer Hensbroek boven dat van den heer van der Chijs, dat hij namelijk van tijdschriften enz. niet slechts de titels en het aantal bladzijden, maar ook den inhoud opgeeft. Op dit oogenblik, bij voorbeeld, zou menigeen gaarne kennis willen maken met de Annals of Achin, zooals die uit het oorspronkelijk vertaald en in 1820-21 te Benkoelen, in de Malayan Miscellanies verschenen zijn. Bij Mr. van der Chijs (bladz. 50, 51) vindt men omtrent die verzameling alleen het volgende vermeld: "1820. Malayan Miscellanies. Benkoelen, 8 o. VI. $+27+16+11+2+14+49+40+32+$ $67+21+108+3+35+12+20+15$ bladz. (XIII nummers). (Sumatran Mission Press). 1822. Malayan Miscellanies. Benkoelen, 80 . Vol. II. $22+98+12+9+12+23+$ III $+96+18+6+2$ $+7+16+16+1+5$ (XV nummers) (Sumatran Mission Press).» Niemand zal beweren dat die cijfers en die plusteekens den lezer veel wijzer maken. Bij Boele van Hensbroek ontmoet men: «W. R. van Hoëvell, de Maleische Bijbelvertaling, een monument van den godsdienstigen zin onzer vaderen, , te vinden in Tijdschrift ter bevordering van Christelijken zin in N. I., Batavia 1846. Ook Mr. van der Chijs noemt dat tijdschrift (bladz. 80 en 82), maar hij zegt niet wat er in staat. In het Aardrijkskundig en Statistisch Woordenboek van N. I. (I. 492) wordt beweerd, dat er maar één jaargang van is verschenen; wat zeker vóor noch tegen den Christelijken zin hier te lande zou pleiten, maar toch in zoover onnauwkeurig is, dat men in de Proeve een tweeden jaargang vermeld vindt. Wie dat echter niet slechts beweerd, maar ook bewezen wil zien, moet eerst de uitslaande tabel, volgende op bladz. 251, raadplegen; en wanneẹr hij de 48 kleine kolommen, waarin dat blad verdeeld is, met den vinger volgt en de jaartallen 1846 en 1847 scherp in het oog houdt, zal hij eindelijk stellig weten, niet wat er in van Hoëvell's Bevordering van den Christelijken zin al zoo wordt aangetroffen, maar dat het Tijdschrift sedert 1848 heeft opgehouden te bestaan. Van zulke negatieve informatien vloeit het boek van den heer van der Chijs onzes inziens te zeer over. Gij waant dat Winter's Romo er niet in voorkomt; maar het gedicht komt er wel degelijk in voor. Het wordt vermeld op bladz. 82 boven aan: «1847. Verhandelingen van het Bataviaasch Genootschap van Kunsten en Wi:36: $20 \mathrm{PM}$ 
cerstgenoemde ettelijke jaren, bedriegen wịj ons niet, zelfs 't vierde eener eeuw, verbonden is geweest aan den dienst der drukpers en boekhandel in Ned. Indië, en in die betrekking in staat was de moeielijkheden, verbonden aau 't samenstellen' van bibliographieën, vooral van eene van Indische drukwerken, van nabij te leeren kennen en te beoordeelen, geeft de laatste ons een staaltjen van zijne bibliographische kennis door, gelijk we zagen, meê te deelen, dat Maisonneuve en $\mathrm{C}_{\mathrm{ie}}$ te Parijgs den catalogus der bibliotheek van Prof. Millies verleden jaar hebben gedrukt, uitgegeven, en gratis of voor weinige stuivers verkrijgbaar gesteld. De waarheid is, dat die Parijsche boekhandelaren ten vorigen jare een' catalogus in 't licht hebben gezonden, waarin beduidend veel voorkwam van tgeen door hen bij de verkooping der boekerij van den Utrechtschen Hoogleeraar is aangekocht geworden 1, maar een boekverkoopersleerling zou 't u hebben kunnen zeggen, dat de rijke bibliotheek van dien hoogleeraar gecatalogiseerd is geworden door den bekenden bibliograaf J. I. Beijers, boekhandelaar te Utrecht en door hem in zijne wouing aldaar van 7 --14 Mei 1870 verkocht.

Hetgeen de schrijver van 't Dagbladartikel zegt van de grondslagen en grenzen eener voor de wetenschap vruchtbare bibliographie van N. I., schijnt, onzes inziens, evenzeer aan bedenking onderhevig. Niets vuriger zouden wij wenschen dan dat er een bibliographisch overzicht gegeven werd van 'tgeen zoowel in ons vroeger als tegenwoordig Nederlandsch-Indië gedrukt is benevens 't geen in vroeger en later tijd over die

schappen. Batavia 8o., 21e deel, 2de gedeelte. $28+569$ bladz. (Drukkerij van het Bat. Gen.)" Aan u de zorg om van elders te weten te komen, wat er in dit en in de vorige twintig deelen der werken van het Genootschap, of in het eerste gedeelte van het $21 \mathrm{e}$ deel, of in het doet niet welk deel van welk ander vervolgwerk of tijdschrift of dagblad, te lezen staat. Daarentegen kunt gij hier uit de eerste hand vernemen waar en wanneer in Indië le Caïd, Ernani, Faust, Martha ou le marché de Richmond, el Trovatore of la Traviata gedrukt zijn, hoe veel reglementen der societeit te Banjermasin de wereld kent, dat aan het reglement voor het lief hebberij-tooneelgezelschap te Pasoeroean, onder de zinspreuk: "liefde tot harmonien, de naam van den uitgever ontbreekt, terwijl integendeel van het reglement voor de verpakking en verzending van vaste vetten met al die v's er in - uitilrukkelijk gezegd wordt, dat het in 80 formaat is verschenen, 5 bladzijden telt en ter Landsdrukkerij te Batavia het licht heeft gezien.

1 We hebben reeds vroeger den catalogus van Maisonneuve besproken in no. II ouzer aKoloniale bibliograptipẹt, hoaded from Brill.com04/26/2023 01:36:20PM 
gewesten in Nederland of in Europa in 't licht is verschenen. Maar of zulk een reuzenwerk met 't oog op 't betrekkelijk weinige dat er nog voor verricht is, en met inachtneming van de eischen, die de bibliographische wetenschap stellen mag, vooralsnog althaus tot de mogelijkheden behoort, is eene vraag, tot de beantwoording waarvan men geene poging heeft gedaan, doch die toch alleszins overweging verdient. $\mathrm{Na}$ de ervaringen, die we ondervonden hebben met opzicht tot de moeielijkheid van de samenstelling eener eenigszins volledige koloniale bibliographie in haar geheelen omvang en de weinige belangstelling, die nog op dat gebied waargenomen wordt, mogen wij reeds dankbaar zijn, waar men zich beijvert gedeelten van 't omvangrijk en nog onontgonnen veld te bearbeiden. Ook de heer van der Chịs begreep terecht dat hij zich eenigermate beperken moest. Waar hij alleen de pers en boekhandel in Indië sedert onze vestiging aldaar tot heden tot onderwerp zijner studiën koos, moest noodwendig buiten zijn kader vallen al 't geen in ons vaderland of in Europa gedrukt is. Het gaat daarom niet aan om, gelijk de Recensent in het Algemeen Dagblad v. N. I. gedaan heeft, er hem een verwijt van te maken dat hij al die vaderlandsche of Europeesche drukwerken niet opgenomen heeft. Iets anders is 't echter, waar de heer van der Chijs meende te kunnen volstaan met alléén te letten op de vruchten der pers in Indië, zoo als wij 't kennen, en zich niet te moeten bezighouden met de drukkerijen gedurende den tijd der Oost-Indische Compagnie te Colombo en elders opgericht. Hierover kan men hem, zonder onbillijk te zijn, ter verantwoording roepen en in herinnering brengen, hoe juist die drukkerịjeu eene eervolle uitzondering makkten op den toestand van letterkundige afhankelijkheid, waarin alle buiten-Europeesche koloniën verkeerden. Ook wij betreuren het, dat Mr. van der Chijs zich te enge grenzen gesteld heeft. Echter maken wij daarvan geen ernstige grief tegen zijn arbeid, in de wetenschap dat zelfs de vervulling der bescheiden taak, die hij op zich nam, reeds moeielijk genoeg zou zijn. Op geen voorganger kon hij wijzen; voorbereid was 't werk slechts luttel; en op wat tal van bezwaren zou hij daarbij niet stuiten! Niet geheel ten onrechte schrijft c'e heer Kolff' in zijne reeds vermelde lofrede: "Het zegt tocn wat: waar niets bestond, betrekkelijk zooveel tot stand te brengen. Hier stonden (uitgenomen misschien de Bibliotheek van het Bataviaasch Genoot-

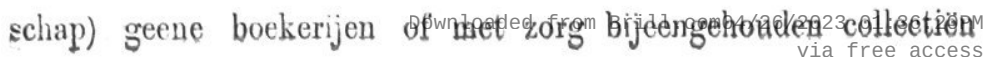


van particulieren hem ten dienste. Behalve de onophoudelijke mutatiën in het Europeesch personeel in Indië, spreekt de heer van der Chijs zeer geestig van "climatologische en entomologische invloeden" (vrij vertaald: stof en vocht; witte mier en boekwurm!) die oude boeken daar spoorloos doen verdwịnen, terwijl de Chinesche vuurwerkmakers jaar aan jaar voor humne petasans (voetzoekers) alle oud gedrukte en ongedrukte papieren in de lucht doen vliegen. Onder die omstandigheden mag het een mirakel heeten, dat de heer van der Chijs nog zooveel boektitels heeft kunnen bijeenzamelen; trouwens sommigen heeft hij werkelijk niet in handen gehad; ze bestaan wellicht niet meer, en hij putte ze uit andere werken."

Dat zijn werk verre van volledig is, de schrijver zelf zal, gelooven we, wel de eerste zijn van dit te erkennen. Gaarne nemen we dan ook aan dat het die verdienste niet bezit. De in dit opzicht aangewezen voorbeelden laten we in al hun kracht gelden; we zouden ze zelfs nog met ettelijke tientallen van geschriften kummen vermeerderen, vooral uit de $17 \mathrm{e}$ eeuw en $18 \mathrm{e}$ eeuw, welke we sedert geruimen tijd voor een gelijk doel hebben verzameld en die we 't voorrecht hadden te vinden in de verschillende boekerijen van ons land zoowel als in de verzameling van het Rijksarchief alhier, waar ze vaak tusschen de ongedrukte stukken verscholen en waarvan sommigen bijna onvindbaar zijn. De heer van der Chijs heeft intusschen gegeven wat hij had en wist, en verder moge hij zich troosten met de gedachte, welke we reeds hierboven uitspraken, dat op bibliographisch terrein volledigheid zeldzaam bereikbaar is.

Ėen andere vraag is het, of hij datgene wat hij geleverd heeft, zoodanig heeft ingericht, dat daartegen geen gegronde bedenkingen kunnen worden ingebracht. En in dit opzicht durven we niet als geheel ongegroud verwerpen wat in het Algemeen Dagblad van N. I., zoowel in 't eerste artikel als later, is aangevoerd. De vermelding van de Naamboeken der hooge regeering, bijna jaar op jaar, van de verschillende couranten, tijdschriften, van de werken van.onderscheidene genootschappen, enz., telkens afzonderlijk in 't jaar, waarin zij 't licht hebben gezien en zooveel meer, mogen ook wij niet goedkeuren; wij zouden het raadzamer hebben gevonden, zoo de schrijver had kunnen besluiten bij den eerst voorkomenden titel van diergelijke geschriften het wetenswaardige in eene min of meer uit-

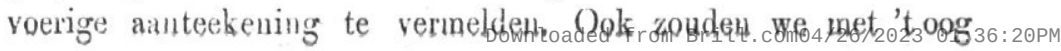


op de aangewezen voorbeelden niet durven ontkennen, dat hij in zijne opgaven steeds die nauwkeurigheid heeft hetracht, welke van en in eene bibliographie geëischt mag worden. Men zij intusschen billijk in zijn oordeel en prijze 't werk niet uitbundig of veroordeele het met voomaamheid. Men erkenne de gebreken; en dat er velen zijn, blijkt uit 't geen er aangevoerd is. Maar daartegenover staan ontegenzeggelijk vele verdiensten. Deze liggen voor een deel zeker daarin dat de heer van der Chijs, waar anderen de hand niet aan den arbeid sloegen, zelf als baanbreker is opgetreden op een weinig of bijna niet ontgonnen veld. Wat ons daarbij ook voornamelijk aantrok en om met den heer Kolff te spreken, daaraan vooral "pikante waarde bijzet", is "dat men er niet slechts eene dorre opsomming van titels vindt, maar deze afgewisseld met zeer merkwaardige aanteekeningen, die getuigen hoe conscientieus de auteur zijn onderwerp bestudeerd heeft en die den lezer tegelijk met een aantal historische bijzonderheden in kennis stellen ten aanzien van het wel en wee van de Indische drukpers in haar doorleefde phasen." De heer Kolff heeft ons reeds merkwaardige proeven van den inhoud dier aanteekeningen. gegeven, waarnaar wij den belangstellenden lezer gaarne verwijzen. Jammer dat de heer van der Chijs zelf in een inleiding ze niet bijeengelezen heeft tot eeu overzicht van het begin, den vooruitgang, de uitbreiding en den bloei der Indische drukpers. Hoewel we gereedelijk erkennen dat zulk een overzicht met 't oog op 't gemis van vele bescheiden en meer dan éen punt dat opheldering behoeft, vooralsnog niet volledig zou kunnen zijn, \%ou het echter als eene eerste proeve toch zijne waarde hebben, evenals de heer van der Chijs er niet voor teruggedeinsd is met opzicht tot de bibliographie zelve te geven wat in zijn vermogen lag.

Eene Proeve betitelt hị zelf met bescheidenheid zịjn geheele werk. Aanvaarden wij 't ook als zoodanig, en al moge men nu daarin menige bibliographische zonde of misvatting ontdekken, ' $t$ is daarom nog niet eene mislukte proeve, evenmin als het kan doorgaan voor een waardig monument, gewijd aan de Indische drukpers en boekhandel. Allerminst verdient het eene kritiek, waarvan de toon ons onwillekeurig de slechte manieren in de pers, eens zoo scherp afgekeurd, weder voor den geest roept.

Den Hagg, 6 October '75. Dr. T. C. L. Wijnmalien. 